\title{
Field-Scale Evaluation of Biosolids-Derived Organomineral Fertilizers Applied to Winter Wheat in England
}

\author{
Diogenes L. Antille,* Richard J. Godwin, Ruben Sakrabani, Saman Seneweera, \\ Sean F. Tyrrel, and A. Edward Johnston
}

\begin{abstract}
Field-scale experiments in four crop seasons established the agronomic performance of biosolids-derived organomineral fertilizers (OMF) for winter wheat (Triticum aestivum L.) production in England. Two OMF formulations $\left(\mathrm{OMF}_{10}\right.$ 10:4:4 and $\mathrm{OMF}_{15}$ 15:4:4) were compared with urea and biosolids granules $(\approx 5: 6: 0.2)$ to determine crop responses and fertilizer effects on soil chemical properties. Fertilizers were applied at $\mathrm{N}$ rates between 0 and $250 \mathrm{~kg} \mathrm{ha}^{-1}$ at regular increments of $50 \mathrm{~kg} \mathrm{ha}^{-1} \mathrm{~N}$. Average grain yields with $\mathrm{OMF}_{10}$ and $\mathrm{OMF}_{15}$ were higher than with biosolids granules, but lower than with urea $(P<0.05)$. The optimum $\mathrm{N}$ application rates, and corresponding grain yields, were 245 and $7900 \mathrm{~kg} \mathrm{ha}^{-1}$ for biosolids, 257 and $9100 \mathrm{~kg} \mathrm{ha}^{-1}$ for $\mathrm{OMF}_{10}, 249$ and $9500 \mathrm{~kg} \mathrm{ha}^{-1}$ for $\mathrm{OMF}_{15}$, and 225 and $10350 \mathrm{~kg} \mathrm{ha}^{-1}$ for urea, respectively. Differences in grain yield between fertilizer treatments were explained by differences in yield components, particularly number of grains and thousand-grain-weight. Grain-N recoveries were $31 \%$ for biosolids, $\approx 40 \%$ for OMF, and $52 \%$ for urea. Organomineral fertilizers-induced changes in soil extractable $\mathrm{P}$ and soil P Index were not significant. Thus, application of OMF replenished $\mathrm{P}$ offtake by the crop and therefore supported the choice of the proposed OMF formulations. By contrast, extractable $\mathrm{P}$ increased in biosolids and decreased in urea-treated soils, respectively. Heavy metals in soil were unaffected by fertilizer treatment and lower than permissible limit values. The use of OMF for winter wheat production appears to be a sustainable approach to recycling biosolids to land.
\end{abstract}

\section{Core Ideas}

- Agronomic efficiency of organomineral fertilizers higher than biosolids granules.

- Organomineral fertilizers reduces the risk of soil P build-up compared with biosolids.

- Conversion of sewage sludge into organomineral fertilizers improves the fertilizer value of biosolids.

\section{Published in Agron. J. 109:654-674 (2017)}

doi:10.2134/agronj2016.09.0495

Received 4 Sept. 2016

Accepted 11 Jan. 2017

Available freely online through the author-supported open access option

Copyright ( 2017 American Society of Agronomy

5585 Guilford Road, Madison, WI 53711 USA

This is an open access article distributed under the CC BY license

(https://creativecommons.org/licenses/by/4.0/)
1 $\boldsymbol{\gamma}_{\text {HE WASTEWATER INDUSTRY recognizes significant }}$ cost advantages in recycling treated sewage sludge (biosolids) to agricultural land compared with alternative, more expensive, disposal options such as landfill and incineration (Evans et al., 2004). In England, the cost of recycling is approximately GBP170 per t of sludge (dry solids, GBP1.00 US\$1.32), including finance and depreciation. Estimates show that landfill and incineration are approximately 30 to $50 \%$ more expensive than agricultural recycling (Milieu Ltd., WRc, Risk \& Policy Analysts Ltd., 2010). Application of biosolids to agricultural land is encouraged by current legislation in Europe, such as the Sewage Sludge Directive 86/278/ EEC, and is considered to be the best practicable environmental option in most circumstances (Council of European Communities, 1986; Kelessidis and Stasinakis, 2012). The European Commission supports this practice provided that the biosolids used on agricultural land do not present a risk to the environment and potential contaminants, such as heavy metals, are not transferred to the food chain (Smith, 2009). Using biosolids is regarded as strategically important to the wastewater industry (Hill, 2005) because agriculture is a potentially significant market for them and for biosolids-derived products as a potential source of plant nutrients, together with the need to avoid costs associated with other disposal routes (Lagae et al., 2009; Delin, 2016).

The disposal strategy for sewage sludge of a major wastewater treatment operator located in the Northwest of England is based on a dual approach of recycling to farmland (about 70\%) and incineration (about $30 \%)$ of the total sludge $(\approx 0.25 \mathrm{Tg}$ per year, dry solids) they produce. At a national U.K. level, the annual production of sludge is approximately $1.5 \mathrm{Tg}$ (dry solids) of which 75\% is reported to be used on farmland (UKWIR, 2015). The relatively high reliance on recycling to agriculture requires that this disposal route is protected and that current levels of

D.L. Antille, University of Southern Queensland, National Centre for Engineering in Agriculture, Toowoomba, QLD, Australia; R.J. Godwin, Harper Adams University, Engineering, Newport, Shropshire, UK; R. Sakrabani, Cranfield University, Soil and Agrifood Institute, Cranfield, Bedfordshire, UK; S. Seneweera, University of Southern Queensland, Centre for Crop Health, Toowoomba, QLD, Australia; S.F. Tyrrel, Cranfield University, Water Science Institute, Cranfield, Bedfordshire, UK; A.E. Johnston, Rothamsted Research, Department of Sustainable Soils and Grassland Systems, Harpenden, Hertfordshire, UK. *Corresponding author (d.l.antille@gmail.com).

Abbreviations: AE, agronomic efficiency; MERN, most economic rate of nitrogen; NUE, nitrogen use efficiency; OMF, organomineral fertilizers; SMN, soil mineral nitrogen; SOM, soil organic matter; TB, total aboveground biomass; TGW, thousand grain weight; TN, total nitrogen; UAN, urea-ammonium nitrate. 
biosolids used by farmers are maintained or increased where possible. The increased price of mineral fertilizers in recent years led an increasing number of farmers to look to organic materials to meet the nutrient requirements of crops and maintain soil fertility (Dawson and Hilton, 2011). Benefits from application of biosolids to agricultural land are well documented (e.g., Bastian, 1997; Chambers et al., 2003; Rigby and Smith, 2014). For example, recycling of biosolids contributes to close the natural $\mathrm{C}$ and nutrients cycles, maintain soil fertility and soil organic matter, and mitigate the depletion of naturally available, although finite resources, such as rock phosphate (Diacono and Montemurro, 2010; Powlson et al., 2012; Reijnders, 2014). However, in practice, recycling biosolids to agriculture presents both the wastewater industry and end-users with several challenges, including: land-bank availability in the proximity of wastewater treatment works, soil $\mathrm{P}$ status and potential $\mathrm{P}$ enrichment of surface waters, the concentrations and phyto-availability of nutrients in biosolids, potential build-up of heavy metals in soil, their uptake by crops grown on the soil and subsequent transfer to the food chain, and logistics issues such as cost of transport, storage, handling and field application (Hogan et al., 2001; Elliott et al., 2002; O'Connor et al., 2004; Clarke and Cummins, 2015). A concern of routine application of biosolids to soil is that the loading rate of $\mathrm{P}$ can be higher than that commonly applied through mineral fertilizers because of their low $\mathrm{N} / \mathrm{P}$ ratio (Higgs et al., 2000; Pritchard et al., 2010). This can lead to progressive build-up of soil P, a problem commonly observed in areas close to production sites, where soils frequently have relatively high soil $\mathrm{P}$ Indices that are above the recommended target index for the soil and cropping system (Skinner and Todd, 1998; DEFRA, 2010; Antille et al., 2014a, 2014b). Combined effects of the relatively low N/P ratio of biosolids (typically less than 1) with soil application rates based primarily on crop $\mathrm{N}$ requirements (Withers et al., 2016) often results in over-application of P relative to crop need. Soil application of $\mathrm{P}$ at rates exceeding offtake is known to raise extractable P levels, particularly in low (e.g., <20\%) clay content soils (Heming, 2007). Surplus P applied to soils in biosolids influences soil $\mathrm{P}$ dynamics, and can enhance the adverse effects of $\mathrm{P}$ in surface water when $\mathrm{P}$ is transferred on eroded soil (Smith et al., 2006; Withers et al., 2009; Wang et al., 2016).

Nevertheless, recycling biosolids to agriculture offers scope for reduced inputs of mineral fertilizers (Hogan et al., 2001), which with increasing prices reduce profit margins to growers (Heffer and Prud'homme, 2013). One important possibility that could increase the use of biosolids in agriculture would be for the wastewater industry to enhance the quality of their products, and one way of doing this would be to produce OMF.

\section{Organomineral Fertilizers}

A novel technology reported in earlier studies (Antille, 2011; Antille et al., 2013c) enables OMF to be produced from treated sewage sludge (biosolids). This technique involves granulating the biosolids and coating the granules with urea $(46 \% \mathrm{~N})$ and muriate of potash $\left(\mathrm{MOP}, 60 \% \mathrm{~K}_{2} \mathrm{O}\right)$ to produce a compound NPK fertilizer material. This has been tested in two formulations with $\mathrm{N} / \mathrm{P}_{2} \mathrm{O}_{5} / \mathrm{K}_{2} \mathrm{O}$ ratios of 15:4:4 $\left(\mathrm{OMF}_{15}\right)$ and 10:4:4 $\left(\mathrm{OMF}_{10}\right)$, respectively (Antille, 2011; Antille et al., 2013c). Physical characteristics such as particle size, size distribution, particle strength, and density were measured to enable field application at tramline spacing of $24 \mathrm{~m}$ (considered to be standard for arable cropping in the United Kingdom) using pneumatic or twin-discs fertilizer applicators (Antille et al., 2015). Field spreading tests conducted with OMF using the transverse tray testing (ASAE Standards, 1999) showed satisfactory results in terms of uniformity of distribution both longitudinally (direction of travel) and transversally (treated swath) (Antille et al., 2015).

A key aspect of this combined agronomic and engineering technology is that consistent fertilizer materials can be produced from sludge by adjusting $\mathrm{N} / \mathrm{P} / \mathrm{K}$ ratios to suit specific requirements for crop and soil. This removes some of the limitations commonly encountered with using biosolids, including: variable chemical composition, and inadequate physical properties for optimal spreading (Sommers et al., 1976; Landry et al., 2006, 2011), with potential to improve nutrient recovery in crop and overall fertilizer value, ease of handling, and efficient field application.

The work reported here extends earlier studies by Antille et al. (2013b, 2014a) conducted at glasshouse- and field-scales on the value of biosolids-derived OMF as amendments for perennial ryegrass (Lolium perenne L.), which showed satisfactory agronomic and environmental performance of OMF, and suggested that such products could be used to extend the use of biosolids on arable land. Consequently, the study reported here assessed the agronomic efficiency and determined the feasibility of using OMF on economically important arable crops, such as winter wheat, grown in the Northwest of England.

\section{Objectives}

The objectives of this study were to: (i) investigate grain yield, yield components, and yield-to-fertilizer response relationships of winter wheat as affected by soil application of biosolids-derived OMF, urea, and biosolids granules, (ii) derive the optimum $\mathrm{N}$ application rate for OMF and urea based on the above yield-to- $\mathrm{N}$ responses, (iii) investigate the effects of OMF on $\mathrm{N}$ uptake and nitrogen use efficiency (NUE) in winter wheat crops, and (iv) investigate changes in soil fertility properties and selected heavy metals in soil as affected by OMF application. It was hypothesized that: (i) the agronomic performance of crops fertilized with OMF would be significantly higher than that of biosolids granules but lower than urea, and (ii) soil application of OMF would not induce significant changes in soil chemistry, particularly soil extractable $\mathrm{P}$ and $\mathrm{K}$. The results of this 4-yr study were used to produce practical recommendations for winter-sown cereals in England.

\section{MATERIALS AND METHODS}

\section{Experimental Sites}

The study was conducted at Cranfield University at Silsoe $\left(52^{\circ} 00^{\prime} 19^{\prime \prime} \mathrm{N}, 0^{\circ} 25^{\prime} 36^{\prime \prime} \mathrm{W}\right)$, located in Bedfordshire, UK. Two experimental sites, referred to as Avenue and Chippies fields, were established in October 2006 and October 2008, respectively. Each site consisted of 605 by $2 \mathrm{~m}$ plots, which were georeferenced to facilitate re-positioning in subsequent years or after pre-plant tillage operations in fall. The dimensions of plots were selected to enable mechanical harvest with a plot combine harvester (Deutz-Fahr M660) equipped with a 2-m wide cutter bar and a system for bagging grain from individual plots. Avenue field had been set-a-side 


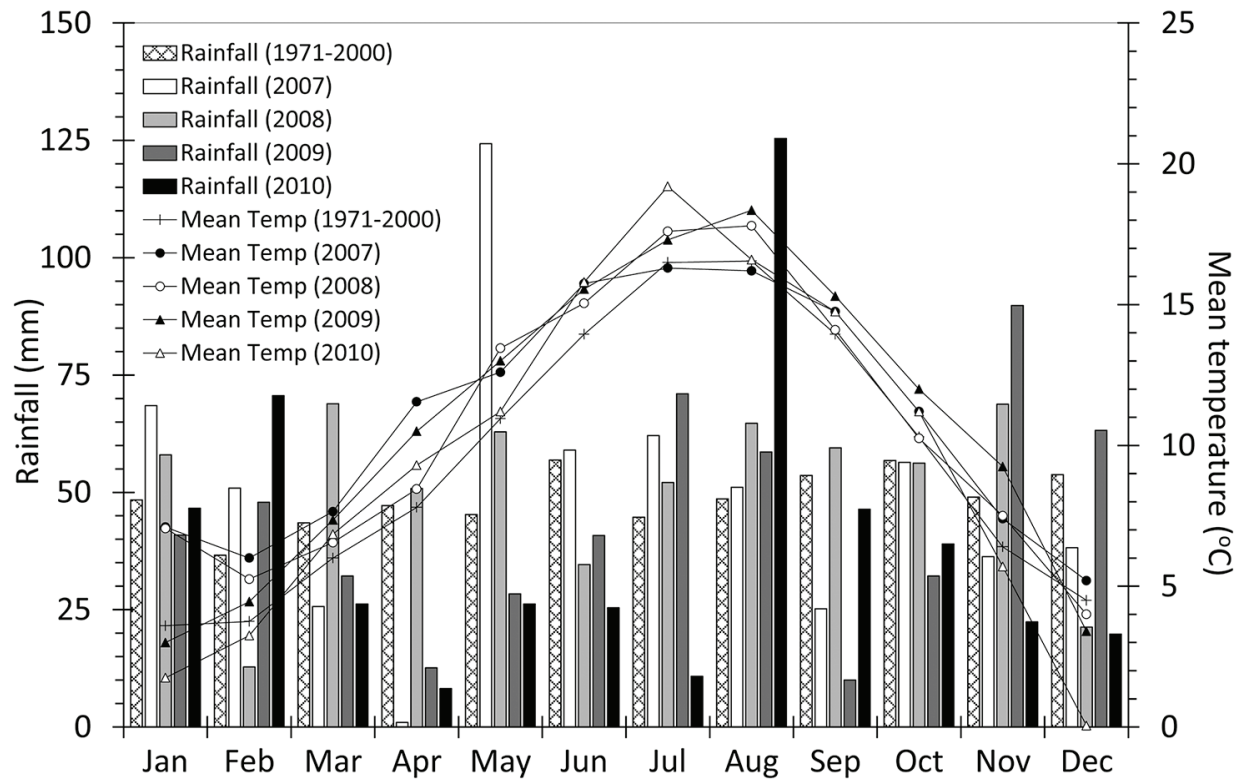

Fig. I. Rainfall and temperature records for Cranfield University at Silsoe, U.K. (after Cranfield University, 20I0).

in 2004-2005 and cultivated to oilseed rape (Brassica napus L.) in the 2005-2006 season (grain yield: $2950 \mathrm{~kg} \mathrm{ha}^{-1}$, $\mathrm{N}$ application rate: $\left.200 \mathrm{~kg} \mathrm{ha}^{-1}\right)$. Chippies field had grown winter wheat in $2006-$ 2007 (grain yield: $9100 \mathrm{~kg} \mathrm{ha}^{-1}, \mathrm{~N}$ application rate: $210 \mathrm{~kg} \mathrm{ha}^{-1}$ ) and oilseed rape in 2007-2008 (grain yield: $2900 \mathrm{~kg} \mathrm{ha}^{-1}, \mathrm{~N}$ application rate: $200 \mathrm{~kg} \mathrm{ha}^{-1}$ ). At both sites, ammonium nitrate $(34 \% \mathrm{~N})$ had been applied to the previous crops.

The soils at both sites are described in King (1969) as Cottenham series sandy loam, which are well drained and have a gentle slope $(<1 \%)$. This soil is similar to that frequently occurring in the Northwest region of England (Ragg et al., 1984), the operating area of the wastewater treatment operator on whose behalf the experiments were done. Soil textural analyses (British Standard, 1990) for the bulked 0- to 200-mm layer were: $67 \%$ sand, $13 \%$ clay, and $20 \%$ silt for Avenue field, and $79 \%$ sand, $11 \%$ clay, and $10 \%$ silt for Chippies field, respectively. Soil bulk density $\left(1.34 \mathrm{~g} \mathrm{~cm}^{-3}\right.$, Antille et al., 2013a) was representative for this depth of this soil series. Moisture content at field capacity ( 0.05 bar, Hall et al., 1977) was 26.6 and $23.4 \%\left(\mathrm{w} \mathrm{w}^{-1}\right)$ for Avenue and Chippies fields, respectively. Rainfall and temperature records for Silsoe are shown in Fig. 1. The mean annual rainfall for 2006 to 2010 was $564 \mathrm{~mm}$, which was similar to historic records (1971-2000), but with relatively higher inter-annual variation. Rainfall in April to June 2010 (70 mm) was half that in 2009 (153 mm), which had implications for fertilizer- $\mathrm{N}$ availability, $\mathrm{N}$ uptake, and crop yield potential. Similar soils in Bedfordshire remain at or above field capacity from around 10 December to 25 March, but usually not later than 20 April. Mean soil moisture deficits of up to 80 and $100 \mathrm{~mm}$ typically occur in June and July, respectively (Smith and Trafford, 1976). Air temperatures during the course of the experiment were slightly above the historic average (Fig. 1).

\section{Experimental Design and Crop Establishment}

Winter wheat was established in 2006-2007 (first crop) and 2007-2008 (second crop) in Avenue field, and in 2008-2009 (first crop) and 2009-2010 (second crop) in Chippies field, respectively. A summary of the crops established and records of fertilizer applications are in Table 1 . The wheat was always sown between the second and third week of October at $150 \mathrm{~kg}$ seeds ha ${ }^{-1}$ with standard agronomic practice; except for the fertilizer application, which was dependent on fertilizer treatment. The wheat varieties were Claire in Avenue field and Nijinsky in Chippies field, both classified as soft endosperm and National Association of British and Irish Flour Millers (NABIM) Group 3.

Two OMF, namely: $\mathrm{OMF}_{10}(10: 4: 4)$ and $\mathrm{OMF}_{15}(15: 4: 4)$ as granules, were compared with urea (46:0:0) and (thermally dried) biosolids granules $(\approx 5: 6: 0.2)$, the $\mathrm{N}$ content of all four was total $\mathrm{N}$. The average total $\mathrm{C}$ content $( \pm \mathrm{SD}, n=4)$ was $27.7 \% \pm$ $5.96\left(\mathrm{OMF}_{15}\right), 26.8 \% \pm 5.75\left(\mathrm{OMF}_{10}\right)$, and $31.3 \% \pm 6.73$ (biosolids granules); additional specifications are reported in Antille

Table I. Crop establishment and timing of fertilizer applications conducted at the experimental sites. Crop growth stages are based on Tottman et al. (1979). UAN is urea-ammonium nitrate ( $30 \% \mathrm{~N}$, solution).

\begin{tabular}{|c|c|c|c|}
\hline Site & Crop (season) & Fertilizer application & Crop growth stage \\
\hline \multirow[t]{3}{*}{ Avenue field } & First wheat (2006-2007) & 27 March 2007, UAN (I00 kg ha-1 N)† & 24-25: main shoot $+4-5$ tillers \\
\hline & First wheat (2006-2007) & 17 May $2007 \ddagger$ & 36-37: sixth node to flag leaf just visible \\
\hline & Second wheat (2007-2008) & 3 April 2008§ & 25-26: main shoot $+5-6$ tillers \\
\hline \multirow[t]{2}{*}{ Chippies field } & First wheat (2008-2009) & 24 March $2009 \S$ & 23-24: main shoot $+3-4$ tillers \\
\hline & Second wheat (2009-2010) & 24 March $2010 \S$ & 21-22: main shoot $+1-2$ tillers \\
\hline
\end{tabular}

$\dagger$ First $\mathrm{N}$ application.

$\ddagger$ Second $\mathrm{N}$ application.

$\S$ Full $\mathrm{N}$ rate (single application). 
et al. (2013c, 2015). Fertilizers were hand-applied at $\mathrm{N}$ rates from 0 (control) to $250 \mathrm{~kg} \mathrm{ha}^{-1}$ at regular increments of $50 \mathrm{~kg} \mathrm{ha}^{-1} \mathrm{~N}$, which was the range and incremental rates of $\mathrm{N}$ used by Welsh et al. (2003) at Cranfield University to develop strategies for spatially variable $\mathrm{N}$ application in wheat. No $\mathrm{N}$ was applied in buffer areas between experimental plots. A sludge granulation machine was designed and constructed to produce the granules (United Utilities Group PLC, 2007 in Antille, 2011), but regrettably this was not fully operational until late April 2007, which delayed production and subsequent delivery of the granular materials for that year. Consequently, it was decided to apply $100 \mathrm{~kg} \mathrm{ha}^{-1} \mathrm{~N}$, as urea-ammonium nitrate (UAN, $30 \% \mathrm{~N}$, solution) on 27 Mar. 2007 to all plots except the controls to ensure that the wheat continued to grow satisfactorily. Subsequently, all fertilizer treatments were applied on 17 May 2007 (Table 1), later than the recommended practice, which is based on the growth stage of the crop (Tottman et al., 1979; DEFRA, 2010). This approach ensured that OMF- and biosolids-treated plots received the designated $\mathrm{P}$ and $\mathrm{K}$ rates, and that potential effects on soil chemistry associated with these treatments could be investigated in subsequent years. Yields from the 2006-2007 experiment enabled useful practical recommendations to be developed, as discussed later. For the second wheat crop in Avenue field, and both crops in Chippies field, fertilizers were applied in a single dressing to all plots and within the recommended time window for the crop growth stage (DEFRA, 2010).

The experiment was laid-out in a completely randomized design with three replicated plots $(n=3)$, with the exception of controls (zero-fertilizer) and the plots treated with $250 \mathrm{~kg} \mathrm{ha}^{-1} \mathrm{~N}$, which were replicated four $(n=4)$ and two $(n=2)$ times, respectively. This arrangement allowed the experiment to be sited with minimum interference from the surrounding commercial crop.

\section{Crop Measurements and Analyses}

Grain yield was determined by harvesting the entire plot area and expressed as $\mathrm{kg} \mathrm{ha}^{-1}$ at $14 \%(\mathrm{w} / \mathrm{w})$ based on the moisture content at harvest. Total aboveground biomass was determined by cutting a $0.5 \mathrm{~m}^{2}$-quadrate sample of the crop at approximately $20 \mathrm{~mm}$ above the soil surface prior to mechanical harvest. These samples were used to determine the following yield components: harvest index, the ratio grain weight-to-total aboveground biomass, based on the sample collected from the quadrate (Donald and Hamblin, 1976); thousand grain weight (TGW) (MAFF, 1986, Method No.: 73); and number of ears per square meter $\left(\right.$ ears $\mathrm{m}^{-2}$ ). Total $\mathrm{N}$ in grain (MAFF, 1986, Method No.: 48) was determined only on samples taken from the first and second wheat crops in Avenue field, and was used to estimate apparent $\mathrm{N}$ recovery in grain by the difference method, and hence NUE. Differences in yield between fertilized and non-fertilized crops, relative to $\mathrm{N}$ applied as fertilizer, were used to denote agronomic efficiency (AE), which was determined for all four crops. These relationships are shown in Eq. [1] and [2], respectively (after Baligar et al., 2001):

$$
\begin{aligned}
& \mathrm{NUE}=\frac{U_{\mathrm{F}}-U_{\mathrm{F}=0}}{\mathrm{~N}_{\mathrm{RATE}}} \times 100 \\
& \mathrm{AE}=\frac{Y_{\mathrm{F}}-Y_{\mathrm{F}=0}}{\mathrm{~N}_{\mathrm{RATE}}}
\end{aligned}
$$

where NUE is nitrogen use efficiency (\%) based on apparent $\mathrm{N}$ recovery in grain, $U_{\mathrm{F}}$ and $U_{\mathrm{F}=0}$ are $\mathrm{N}$ recoveries in grain $\left(\mathrm{kg} \mathrm{ha}^{-1} \mathrm{~N}\right)$ from fertilized- and non-fertilized (control) crops, respectively, and $\mathrm{N}_{\text {RATE }}$ is $\mathrm{N}$ application rate $\left(\mathrm{kg} \mathrm{ha}^{-1}\right)$. AE is agronomic efficiency $\left(\mathrm{kg} \mathrm{kg}^{-1}\right), Y_{\mathrm{F}}$ and $Y_{\mathrm{F}=0}$ are grain yields $\left(\mathrm{kg} \mathrm{ha}^{-1}\right)$ corresponding to fertilized- and non-fertilized (control) crops, respectively.

Yield-to-N response relationships were examined by applying nonlinear regression analyses, and by fitting quadratic functions (Eq. [3]) to the data (Abraham and Rao, 1966). The approach described here (Eq. [4]-[8]) is from studies (James and Godwin, 2003; Kachanoski, 2009) dealing with cereal

Table 2. Soil chemical analyses conducted prior to the establishment of experimental plots at Cranfield University at Silsoe (Bedfordshire, UK). The standard deviation (SD) is shown as \pm the mean value $(n=3)$, except when not shown $(n=1)$. Sampling depth is $200 \mathrm{~mm}$. Analytical procedures and sampling depth are equivalent to those used in routine soil analyses during the course of the experimental

\begin{tabular}{|c|c|c|c|}
\hline Determination/Site & Avenue field (February 2007) & Chippies field (March 2009) & Analytical method \\
\hline Total C, \%, w w - $^{-1}$ & $1.60 \pm 0.07$ & $\mathrm{I} .5 \mathrm{I} \pm 0.0 \mathrm{I}$ & British Standard (1995a). \\
\hline Total N, \%, w w $w^{-1}$ & $0.15 \pm<0.01$ & $0.13 \pm<0.01$ & British Standard (200I). \\
\hline Total P, mg kg-1 & $1208.1 \pm 106.7$ & $1028.6 \pm 326.4$ & British Standard (1998). \\
\hline Soil pH & $7.11 \pm 0.04$ & $7.09 \pm 0.04$ & MAFF (I 986), Method no.: 32. \\
\hline SOM, \%, w w $w^{-1}$ & $3.87 \pm 0.05$ & $3.43 \pm 0.12$ & MAFF (I986), Method no.: 56. \\
\hline Soil mineral $\mathrm{N}, \mathrm{mg} \mathrm{kg}^{-1}$ & $\mathrm{I} .33 \pm 0.07$ & $3.90 \pm 1.32$ & MAFF (1986), Method no.: 53. \\
\hline Extractable $\mathrm{P}, \mathrm{mg} \mathrm{kg}^{-1}$ & $68.3 \pm 0.33$ & $61.4 \pm 0.72$ & Olsen et al. (1954), British Standard (1995b). \\
\hline Soil P Indext & 5 & 5 & DEFRA $(20 \mid 0)$ \\
\hline Extractable $\mathrm{K}, \mathrm{mg} \mathrm{kg}^{-1}$ & $211.7 \pm 1.44$ & $203.5 \pm 12.40$ & MAFF (I986), Method no.: 63. \\
\hline Soil K Indext & 3 & 3 & DEFRA $(2010)$ \\
\hline $\mathrm{Cd}, \mu \mathrm{kg}^{-1}$ & $167.0 \pm 3.1$ & - & British Standard (1998). \\
\hline $\mathrm{Cu}, \mu \mathrm{g} \mathrm{kg}^{-1}$ & $14.0 \pm 0.6$ & - & British Standard (1998). \\
\hline $\mathrm{Zn}, \mu \mathrm{g} \mathrm{kg}^{-1}$ & $49.0 \pm 3.5$ & - & British Standard (1998). \\
\hline $\mathrm{Pb}, \mu \mathrm{g} \mathrm{\textrm {kg } ^ { - 1 }}$ & $19.8 \pm 2.4$ & - & British Standard (1998). \\
\hline
\end{tabular}
work (2006-2010).

† Soil $\mathrm{P}$ Index 5 equates to Olsen $\mathrm{P}$ range $7 \mathrm{I}-100 \mathrm{mg} \mathrm{\textrm {L } ^ { - 1 }}$, and soil $\mathrm{K}$ Index 3 equates to ammonium nitrate extractable $\mathrm{K}_{\text {range }} 24 \mathrm{I}$ to $400 \mathrm{mg} \mathrm{L}^{-1}$ (DEFRA, 2010). SOM is soil organic matter, (-) not measured. 
crop responses to applied $\mathrm{N}$ fertilizer, and assumes a quadraticplateau relationship, as follows:

$$
y=a+b x-c x^{2}
$$

where $a, b$, and $c$ are regression coefficients, $x$ is $\mathrm{N}$ application rate, and $y$ is grain yield. The lowest $\mathrm{N}$ application rate at which the maximum yield is obtained is derived by equating the first order differential to zero (Eq. [4] and [5]):

$$
\frac{d y}{d x}=b-2 c x^{\prime}=0
$$

Therefore,

$$
x^{\prime}=\frac{b}{2 c}
$$

where $x^{\prime}$ is the (lowest) $\mathrm{N}$ application rate at which the maximum yield $\left(Y_{\text {MAX }}\right)$ is obtained, and where $x \leq x^{\prime}$. The $\mathrm{N}$ rate corresponding to $x^{\prime}$ will be referred to as $\mathrm{N}_{\text {MAX }}$. Subsequently, the most economic rate of nitrogen (MERN) is obtained when the differential is equated to the price ratio $\left(P_{\mathrm{R}}\right)$, as follows:

$$
b-2 c x^{\prime}=P_{\mathrm{R}}
$$

and,

$$
P_{\mathrm{R}}=\frac{P_{\mathrm{N}}}{P_{\mathrm{G}}}
$$

Therefore,

$$
\operatorname{MERN}=\frac{b-P_{\mathrm{R}}}{2 c}
$$

where $P_{\mathrm{R}}$ is price ratio, $P_{\mathrm{N}}$ is price of $\mathrm{N}$ fertilizer $\left(\mathrm{GBP} \mathrm{kg}^{-1}\right)$, $P_{\mathrm{G}}$ is price of grain $\left(\mathrm{GBP} \mathrm{kg}{ }^{-1}\right)$, and MERN is the most economic rate of $\mathrm{N}$ application $\left(\mathrm{kg} \mathrm{ha}^{-1}\right)$ for a given price ratio $P_{\mathrm{R}}$. Price ratio and MERN calculations were based on $P_{\mathrm{N}}$ and $P_{\mathrm{G}}$ for the corresponding year of harvest based on data from Nix (2010). Price ratio is equivalent to the breakeven ratio and indicates the extra return of the grain that just covers the extra unit of $\mathrm{N}$ added. At this point, the economic return from the $\mathrm{N}$ applied as fertilizer is maximized. This analysis uses $P_{\mathrm{N}}$ equivalent to the average price of urea $\mathrm{N}$ paid by U.K. farmers in the corresponding cropping season. For biosolids, $P_{\mathrm{N}}$ is zero because the material can be sourced from wastewater operators at no cost to farmers. Therefore, biosolids' MERN and $\mathrm{Y}_{\text {MERN }}$ are equivalent to $\mathrm{N}_{\mathrm{MAX}}$ and $Y_{\mathrm{MAX}}$, respectively.

\section{Soil Chemistry}

Data for soil chemical analyses on samples taken initially denote baseline levels and are shown in Table 2. Subsequently, soil sampling and analyses on all plots determined fertilizerinduced changes on selected properties (Table 3). In Avenue field, the experimental plots were maintained for two more years following harvest of the second wheat crop in September 2008. The site was fallowed in during winter 2008-2009 and then ryegrass was sown on 30 Mar. 2009 (Antille et al., 2013b). The same fertilizer treatments to those used on the wheat were applied to the grass in the springs of 2009 and 2010, and yields were measured until the experiment was terminated in August 2010. This allowed fertilizer treatment $\times$ crops interaction effects on soil chemical properties to be measured over $4 \mathrm{yr}$ and related to a wider range of weather conditions. Results on the agronomic response of ryegrass to OMF are in Antille et al. (2013b, 2014a).

Soil P Index $>2$ usually indicates that soil P levels are satisfactory for most arable crops and grass grown on mediumtextured soils (DEFRA, 2010), and therefore application of P-based fertilizer may not be required. Because of the risk of transfer of $\mathrm{P}$ to water courses, mainly in eroded soil, it is generally recommended that soils are not raised to more than

\begin{tabular}{|c|c|}
\hline Determination & Timing of sampling and analysis \\
\hline \multirow[t]{2}{*}{ Total $\mathrm{N}$ in soil } & Post-harvest of second wheat: $2007-2008 \dagger, 2009-2010 \ddagger$ \\
\hline & End of the experiment (grass, 2010)† \\
\hline \multirow[t]{3}{*}{ Soil mineral $\mathrm{N}$} & Annually, before fertilizer application $\dagger, \ddagger$ \\
\hline & Annually, post-harvest of first and second wheat $\dagger, \ddagger$ \\
\hline & Annually, after last cut of grass $(2009,2010) \dagger$ \\
\hline Extractable $P$, soil $P$ Index & $\begin{array}{c}\text { Post-harvest of second wheat: } 2007-2008 \dagger, 2009-2010 \ddagger \\
\text { End of experiment (grass, } 2010) \dagger\end{array}$ \\
\hline Extractable K, soil K Index§ & $\begin{array}{c}\text { Post-harvest of second wheat: 2007-2008† } \\
\text { End of experiment (grass, 2010)† }\end{array}$ \\
\hline Soil pH, SOM & $\begin{array}{c}\text { Post-harvest of second wheat: } 2007-2008 \dagger, 2009-2010 \ddagger \\
\text { End of experiment (grass, 2010) } \dagger\end{array}$ \\
\hline \multirow[t]{2}{*}{ Heavy metals in soil: $\mathrm{Cd}, \mathrm{Cu}, \mathrm{Zn}, \mathrm{Pb}$} & Post-harvest of second wheat: 2007-2008† \\
\hline & End of experiment (grass, 20I0) $\dagger$ \\
\hline
\end{tabular}
P Index 3. Levels much higher than this are not uncommon in areas near-sludge production sites because of application

Table 3. Description of soil chemical analyses conducted routinely at the experimental sites, ( $\dagger$ ): Avenue field, and ( $\ddagger$ ): Chippies fields (Cranfield University at Silsoe, UK). Analytical methods and sampling depth are equivalent to those reported in Table 2. For all fertilizer treatments use $n=3$, except controls $(n=4)$ and plots treated with $250 \mathrm{~kg} \mathrm{ha}^{-1} \mathrm{~N}(n=2)$.

$\dagger$ Avenue field.

$\ddagger$ Chippies field.

$\S$ Sampling and analyses performed on control (zero-fertilizer) plots, and plots treated with field equivalent rates of 150 and $250 \mathrm{~kg}$ ha ${ }^{-1} \mathrm{~N}$.

II Sampling and analyses performed on control (zero-fertilizer) plots, and plots treated with field equivalent rates of 150 and $250 \mathrm{~kg} \mathrm{ha}{ }^{-1} \mathrm{~N}$. 

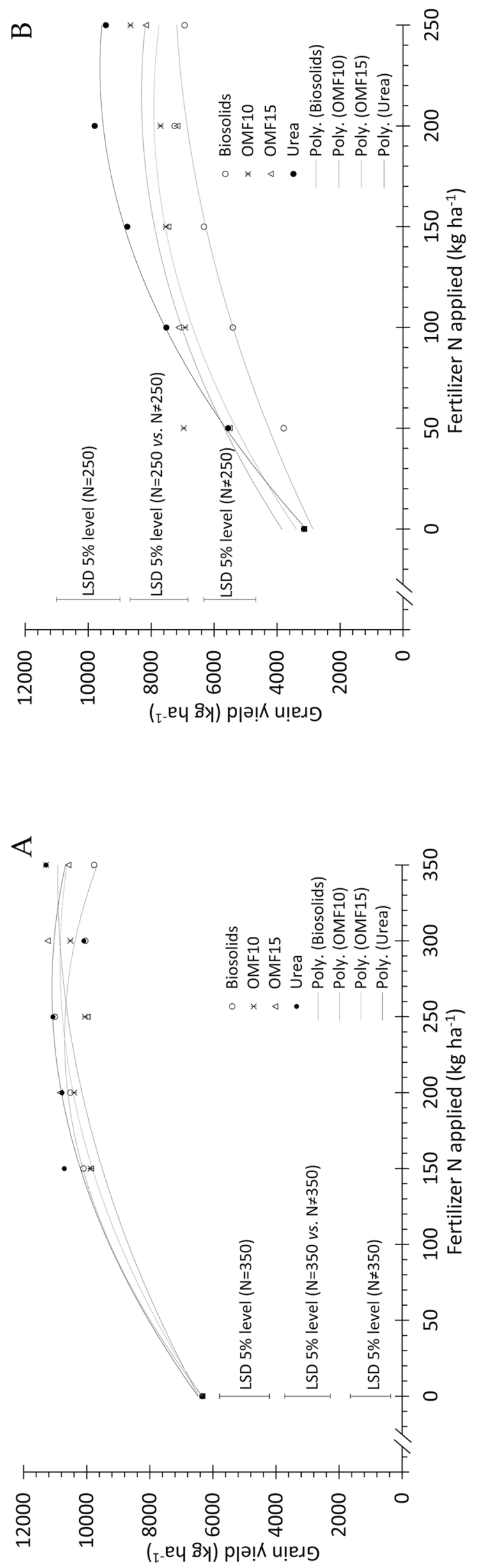

of sewage sludge over many years (Skinner and Todd, 1998; Oliver et al., 2006). Thus, this reduces the land-bank available for recycling. The proposed OMF formulations were designed to enable their regular application without increasing the risk of soil $\mathrm{P}$ build-up due to the higher N/P ratio than that found in biosolids (Antille, 2011; Antille et al., 2013c). Furthermore, OMF was added to already high $\mathrm{P}$ soil to test the efficacy of $\mathrm{P}$ release to replenish the pool that is utilized by the crop so that $\mathrm{P}$ level is maintained. The main purpose of this approach was to ensure that recycling could be continued on the existing landbank, and at an affordable cost to the wastewater industry. In the longer term, this would also ensure that soil P levels within intensively managed arable land would not fall below critical levels for soil and crop, due to omission of $P$ fertilization (Johnston et al., 2013). Long-term omission of P fertilization in such land may run-down plant-available P below threshold levels, which has adverse effects on yield and NUE (Poulton et al., 2013; Johnston et al., 2016).

Soil K Index 3 also denotes a satisfactory K level for wheat production on medium-textured soils (DEFRA, 2010). Enhanced uptake of soil $\mathrm{K}$ was expected in plots treated with relatively high $\mathrm{N}$ rates (e.g., $\geq 150 \mathrm{~kg} \mathrm{ha}^{-1} \mathrm{~N}$ ) and on urea-treated plots, because of the positive $\mathrm{N} \times \mathrm{K}$ interaction (Aulakh and Malhi, 2005) leading to a faster depletion of soil extractable K. A similar effect was to be expected in biosolidstreated soil because of the low content of $\mathrm{K}$ in biosolids granules, but to lesser extent than with urea owing to low $\mathrm{N}$ availability in biosolids (Antille et al., 2014c). Hence, monitoring of soil $\mathrm{K}$ status focused only on changes in soil extractable $\mathrm{K}$ in control plots and plots treated with 150 and $250 \mathrm{~kg} \mathrm{ha}^{-1}$ $\mathrm{N}$. It was hypothesized that addition of $\mathrm{K}$ as OMF would mitigate run-down of soil extractable $\mathrm{K}$ to a greater extent than urea or biosolids granules alone.

Although the focus of this work was not on the impact of sludge-derived products on heavy metals in soil (e.g., Dudka and Miller, 1999), there was a need to determine potential cumulative effects associated with the use of OMF. Soil pH and the heavy metal content in the soils were measured at the sites prior to the experiment (Table 2), together with their amount in all four fertilizer materials (Antille et al., 2013c). Subsequently, heavy metal content was only measured in soil in Avenue field both after harvest of the second wheat and at the end of the $4 \mathrm{yr}$ before the experiment was stopped.

\section{Statistical Analyses}

Statistical analyses for crop and soil data used GenStat Release 16th Edition (VSN International Ltd., 2013), and involved ANOVA and repeated measurement of ANOVA, respectively. The least significant differences (LSD) were used to compare means with a probability level of 5\%. Statistical analyses were graphically assessed by means of residual plots and normalization of data was not required. Yield-to-N responses were investigated by means of nonlinear (quadratic) regression analyses. Linear (simple) responses were also tested and results are discussed. Linear regression analyses were applied to examine the relationships between crop yield components and grain $\mathrm{N}$ with $\mathrm{N}$ application rate, respectively. Nonlinear regression analyses were used to describe NUEto-N application rate responses, from which NUE and AE 
corresponding to MERN were derived. Analytical values are reported as the mean \pm standard deviation $(\mathrm{SD})$.

\section{RESULTS}

\section{Grain Yield and Fertilizer Response}

Yield-to-N responses are shown in Fig. 2 and 3 for the crops grown in Avenue and Chippies fields, respectively. Equations describing these relationships are given in Table 4. Differences in grain yield between control and treatments were always significant $(P<0.001)$. In Fig. 2a differences between fertilizer treatments were not significant, and there was no interaction between fertilizer type and $\mathrm{N}$ application rate $(P>0.05)$. The lack of statistical differences in grain yield in 2006-2007 was attributed to the blanket application of $\mathrm{N}$ as UAN as the first application (growth stage 24-25) as well as the timing of the second application (growth stage 36-37). The second $\mathrm{N}$ application should have been conducted at early stem extension (growth stage 30-31) or approximately 2 to $3 \mathrm{wk}$ after the first application.

Nitrogen applied to the second wheat crop in Avenue field (2007-2008) was slightly delayed due to low temperatures and snow recorded at the site in late March 2008 (Fig. 1). There were significant fertilizer type and $\mathrm{N}$ application rate effects on grain yield $(P<0.001)$. The fertilizer type effect was mainly due to differences between urea and biosolids granules, which produced significantly higher and lower grain yields, respectively, than the two OMF products. OMF 10 produced relatively higher yields than $\mathrm{OMF}_{15}$ across all $\mathrm{N}$ application rates (Fig. 2b), which may be explained by poorer physical quality of $\mathrm{OMF}_{15}$ (particle size and size distribution). Particle size analyses were conducted and reported the following mean diameters $( \pm \mathrm{SD}): 2.72 \pm 7.06 \mathrm{~mm}$ and $3.10 \pm 1.98 \mathrm{~mm}$ for $\mathrm{OMF}_{15}$ and $\mathrm{OMF}_{10}$, respectively $(P<0.05) . \mathrm{OMF}_{15}$ had approximately $15 \%$ (by weight) of particles smaller than $1 \mathrm{~mm}$ in diameter compared with $3 \%$ (by weight) in $\mathrm{OMF}_{10}$. Similar differences between the two materials were observed for particles larger than $5.50 \mathrm{~mm}$ in diameter. Optimum particle size range for OMF is 1.10 to $5.50 \mathrm{~mm}$ in diameter with about $80 \%$ (by weight) between 2.50 and $4.10 \mathrm{~mm}$ in diameter, respectively (Antille et al., 2015). Failure to achieve this optimum range is likely to result in non-uniform spreading, particle segregation, and poor fertilizer use efficiency.

The first wheat crop in Chippies field (2008-2009) showed significant $\mathrm{N}$ application rate, fertilizer type, and interaction fertilizer type $\times \mathrm{N}$ application rate effects on grain yield $(P<$ $0.05)$. For a given $\mathrm{N}$ rate, grain yield tended to be larger when the $\mathrm{N}$ concentration in the fertilizer material was higher, particularly the readily available $\mathrm{N}$ fraction. For the OMF used in 2008-2009 there was no variation in particle size, which therefore supports the fertilizer-N concentration effect on yield. Mean grain yield with biosolids granules alone was approximately 5 and $17 \%$ lower than $\mathrm{OMF}_{10}$ and $\mathrm{OMF}_{15}$, and $23 \%$ lower than urea $(P<0.05)$, respectively (Table 4$)$.

The second wheat crop (2009-2010) in Chippies field showed similar responses to those seen in the first crop (20082009), despite consistently lower yields observed across the entire range of $\mathrm{N}$ application rates. Overall, differences in grain yield were significant with respect to the $\mathrm{N}$ application rate and fertilizer type $(P<0.001)$, but there was no fertilizer type $\times \mathrm{N}$ application rate effect $(P=0.13)$.

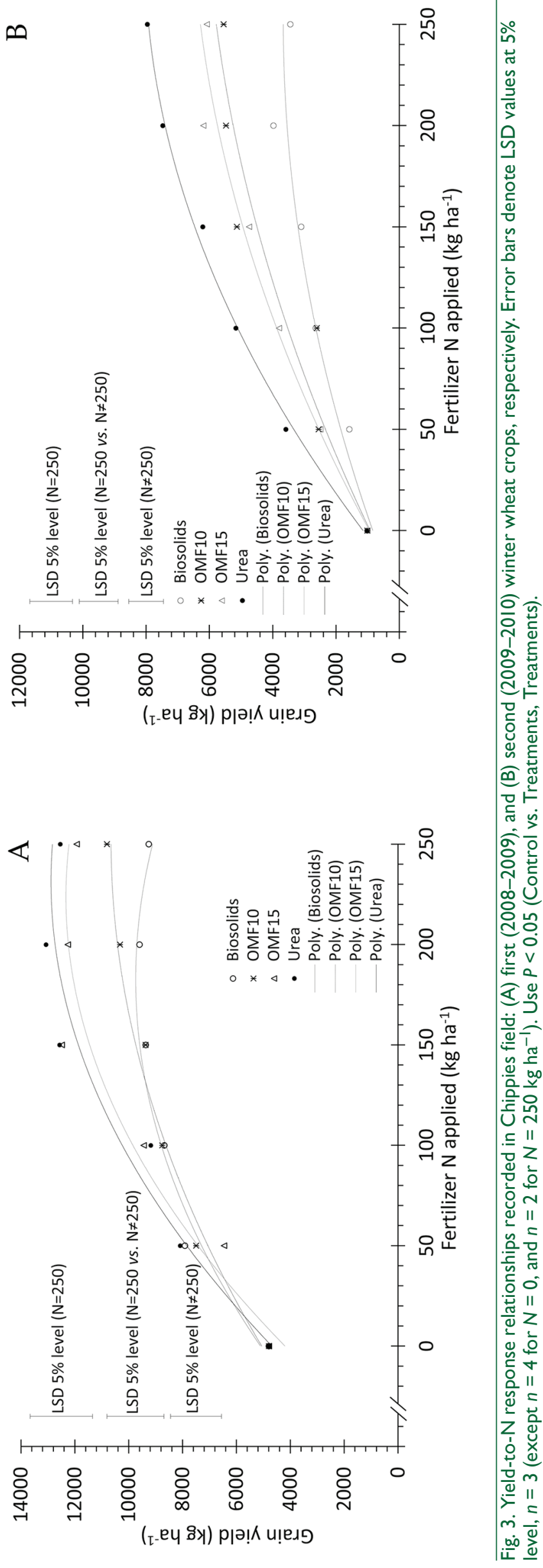


Table 4. Mean grain yield and equations describing the yield-to-nitrogen response relationships recorded for Avenue and Chippies fields from 2006-2007 to 2009-20I0. Different letters indicate that mean values are significantly different at a $95 \%$ confidence interval. The standard deviation (SD) is shown as \pm the mean value. SE is standard error. For mean values use $n=4$ (control), $n=14$ (treatments).

\begin{tabular}{|c|c|c|c|c|c|}
\hline Treatment & Mean yield $\dagger$ & Response & $P$ & SE & $R^{2}$ \\
\hline \multicolumn{6}{|c|}{$\mathrm{kg} \mathrm{ha}^{-1}$} \\
\hline Avenue field & & & 2007 & & \\
\hline Control & $6,332 a \pm 252$ & - & - & - & - \\
\hline Biosolids granules & $10,325 b \pm 654$ & $y=6326+37.4 x-0.08 x^{2}$ & $<0.001$ & 524 & 0.90 \\
\hline $\mathrm{OMF}_{10}$ & $10,367 b \pm 749$ & $y=6437+26.9 x-0.04 x^{2}$ & $<0.001$ & 692 & 0.84 \\
\hline $\mathrm{OMF}_{15}$ & $10,498 b \pm 96 \mid$ & $y=6366+31.2 x-0.05 x^{2}$ & $<0.001$ & 886 & 0.78 \\
\hline Urea & $\mathrm{I0,75} \mathrm{Ib} \pm 724$ & $y=6456+35.7 x-0.07 x^{2}$ & $<0.001$ & 913 & 0.91 \\
\hline Avenue field & & & 2008 & & \\
\hline Control & $3,145 a \pm 544$ & - & - & - & - \\
\hline Biosolids granules & $5,869 b \pm 1575$ & $y=2876+30.1 x-0.05 x^{2}$ & $<0.001$ & 929 & 0.73 \\
\hline $\mathrm{OMF}_{10}$ & $7,477 c, d \pm 1192$ & $y=3827+42.7 x-0.1 x^{2}$ & $<0.001$ & 1273 & 0.60 \\
\hline $\mathrm{OMF}_{15}$ & $7,010 c \pm 1106$ & $y=3384+36 x-0.07 x^{2}$ & $<0.001$ & 1082 & 0.68 \\
\hline Urea & $8,126 d \pm 1790$ & $y=3087+56.9 x-0.12 x^{2}$ & $<0.001$ & 787 & 0.90 \\
\hline Chippies field & & & 2009 & & \\
\hline Control & $4,796 a \pm 352$ & - & - & - & - \\
\hline Biosolids granules & $8,93 \mathrm{lb} \pm 1226$ & $y=5102+50.8 x-0.14 x^{2}$ & $<0.001$ & 1068 & 0.71 \\
\hline $\mathrm{OMF}_{10}$ & $9,247 b \pm 1223$ & $y=5055+44.8 x-0.09 x^{2}$ & $<0.001$ & 559 & 0.93 \\
\hline $\mathrm{OMF}_{15}$ & $10,416 c \pm 2524$ & $y=4212+71.9 x-0.16 x^{2}$ & $<0.001$ & 975 & 0.91 \\
\hline Urea & $10,980 c \pm 2426$ & $y=4701+70 x-0.15 x^{2}$ & $<0.001$ & 1252 & 0.85 \\
\hline Chippies field & & & 2010 & & \\
\hline Control & $\mathrm{I}, 0 \mathrm{I} \mathrm{Ia} \pm 394$ & - & - & - & - \\
\hline Biosolids granules & $2,911 \mathrm{~b} \pm 964$ & $y=849+21.8 x-0.04 x^{2}$ & $<0.001$ & 518 & 0.80 \\
\hline $\mathrm{OMF}_{10}$ & $4,169 c \pm 1605$ & $y=960+28.4 x-0.03 x^{2}$ & $<0.001$ & 916 & 0.77 \\
\hline $\mathrm{OMF}_{15}$ & $4,489 d \pm 1609$ & $y=956+31.7 x-0.04 x^{2}$ & $<0.001$ & 659 & 0.89 \\
\hline Urea & $5,939 e \pm 1669$ & $y=1145+48.1 x-0.08 x^{2}$ & $<0.001$ & 474 & 0.96 \\
\hline
\end{tabular}

† Mean values over the range of $\mathrm{N}$ application rates used in these experiments, except for controls (zero-fertilizer). Compare mean values betweenfertilizer treatments, and within year and site.

For all crops, the regression analyses showed that yield-to-N responses were significant $(P<0.001)$ when a quadratic model was fitted to the data (Table 4 ). For the second wheat crops, the estimates of parameters for the square term in biosolids, $\mathrm{OMF}_{10}$ and $\mathrm{OMF}_{15}$ did not show significance $(P>0.05)$. By eliminating the quadratic term from the model and converting it to linear, and subsequently re-running the analysis, the response remained significant for both the model and the linear term. Therefore, the yield-to- $\mathrm{N}$ response (second wheat) for biosolids, $\mathrm{OMF}_{10}$ and $\mathrm{OMF}_{15}$ could be also explained by linear functions. This linear response was not observed for urea because the square term of the quadratic model was always significant $(P<0.05)$. Despite this, quadratic functions may be justified as all responses produced acceptable fits $\left(R^{2}>0.60\right)$ with all fertilizer materials. This appears to be a fair justification based on the work of Sparrow (1979). Quadratic models provide a more satisfactory biological description of the yieldto- $\mathrm{N}$ response, and therefore may be used despite of non-statistical significance of the quadratic term (Shaohua et al., 1999).

Table 5 shows MERN and $Y_{\text {MERN }}$ calculations derived from the yield-to- $\mathrm{N}$ responses reported in Table 4, and the corresponding price ratios $\left(P_{\mathrm{R}}\right)$ for the year of harvest. The higher $P_{\mathrm{R}}$ in 2008 reflects a faster increase in fertilizer $\mathrm{N}$ price relative to grain price. Prices $\left(\mathrm{GBP} \mathrm{kg}{ }^{-1}\right)$ increased from 0.42 in 2007 to 1.04 in 2008 for fertilizer N, and from 0.10 to 0.12 for wheat (feed), respectively (Nix, 2010). Overall differences in $Y_{\text {MERN }}$ or MERN between-fertilizers were not significant $(P>0.05)$. However, if $Y_{\text {MERN }}$ for 2006-2007 is removed

Table 5. Most economic rate of nitrogen (MERN) and corresponding grain yield ( $\left.Y_{M E R N}\right)$ derived from the yield-to- $N$ responses reported in Table 4. $P_{R}$ is price ratio, SD is standard deviation.

\begin{tabular}{|c|c|c|c|c|c|c|c|c|c|}
\hline \multirow{2}{*}{$\begin{array}{c}\text { Fertilizer } \\
\text { Crop season }\end{array}$} & \multirow[b]{2}{*}{$P_{R}$} & \multicolumn{2}{|c|}{ Biosolids $†$} & \multicolumn{2}{|c|}{$\mathrm{OMF}_{10}$} & \multicolumn{2}{|c|}{$\mathrm{OMF}_{15}$} & \multicolumn{2}{|c|}{ Urea } \\
\hline & & $N_{\text {MAX }}$ & $Y_{\text {MAX }}$ & MERN & $Y_{\text {MERN }}$ & MERN & $Y_{\text {MERN }}$ & MERN & $Y_{\text {MERN }}$ \\
\hline & $\mathrm{kg} \mathrm{kg}^{-1}$ & & & 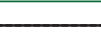 & - kg h & & & & \\
\hline 2006-2007 & 4.28 & 236 & 10,734 & 274 & 10,707 & 248 & 10,765 & 227 & 10,992 \\
\hline 2007-2008 & 8.22 & 302 & 7,418 & 166 & 8,052 & 190 & 7,591 & 198 & 9,525 \\
\hline 2008-2009 & 4.63 & 182 & 9,716 & 222 & 10,542 & 213 & 12,372 & 220 & 12,925 \\
\hline $2009-2010$ & 4.92 & 267 & 3,761 & 368 & 7,083 & 342 & 7,222 & 257 & 7,947 \\
\hline Overall mean & - & 247 & 7,908 & 257 & 9,096 & 249 & 9,488 & 226 & 10,347 \\
\hline SD & - & 51.1 & $3,092.4$ & 85.7 & 1810.3 & 67.1 & $2,495.7$ & 24.4 & $2,|2| . \mid$ \\
\hline
\end{tabular}

† For biosolids granules values of MERN and $Y_{\text {MERN }}$ equate to $N_{\text {MAX }}$ and $Y_{\text {MAX }}$, respectively, as defined in Eq. [5]. 
from the dataset, differences become significant at a $10 \%$ probability level, which is due to lower $Y_{\text {MERN }}$ in biosolids compared with the other treatments. Maximum yield ( $\left.Y_{\text {MAX }}\right)$ of all four crops varied significantly from year to year due to both fertilizer type and seasonal variation in weather, particularly rainfall. Greater variability in $Y_{\mathrm{MAX}}$ was observed with biosolids $\left(\mathrm{SD}=3092 \mathrm{~kg} \mathrm{ha}^{-1}\right.$ ) compared with OMF or urea $\left(\mathrm{SD} \leq 2280 \mathrm{~kg} \mathrm{ha}^{-1}\right)$. Mean values of $Y_{\mathrm{MAX}}\left(\mathrm{kg} \mathrm{ha}^{-1}\right)$ were: 7908 (biosolids), $9226\left(\mathrm{OMF}_{10}\right), 9614\left(\mathrm{OMF}_{15}\right)$, and 10425 (urea), respectively.

\section{Yield Components}

Thousand grain weight showed significant differences between fertilizer treatments, except for the first wheat crop in Avenue field (2006-2007), and therefore was consistent with grain yield data. Differences in TGW were also significant between control $(39.4 \pm 5.13 \mathrm{~g})$ and treatments $(42.8 \pm 4.41 \mathrm{~g})$ in all crops $(P<0.05)$. There was a positive, although nonsignificant linear relationship (TGW $=40.02+0.012 \mathrm{~N}_{\text {Rate }}$, $\left.R^{2}=0.30, P=0.26, \mathrm{SE}=3.76\right)$ between TGW and $\mathrm{N}$ application rate, which suggests a stronger number of grains $\times \mathrm{N}$ rate effect on grain yield. Number of ears per $\mathrm{m}^{2}$ increased with increasing $\mathrm{N}$ application rate $\left(\right.$ Ears $\mathrm{m}^{-2}=396.8+0.47 \mathrm{~N}_{\text {Rate }}$, $R^{2}=0.51, P=0.002, \mathrm{SE}=46.4$ ), which reflects a greater sensitivity of grain yield to changes in number of grains (Fischer, 2008). A fertilizer type effect on ears per $\mathrm{m}^{2}$ (urea $>$ OMF > biosolids, $P<0.05$ ) was observed in all crops with the exception of the first wheat in Avenue field (2006-2007), possibly due to the blanket application of $\mathrm{N}$ in early spring. Overall, mean TGW increased in the order: biosolids $(40.8 \pm 4.70 \mathrm{~g})$, $\mathrm{OMF}_{10}(41.4 \pm 4.61 \mathrm{~g}), \mathrm{OMF}_{15}(42.8 \pm 3.70 \mathrm{~g})$, and urea $(43.9 \pm 3.89 \mathrm{~g})$, respectively. There was a fertilizer type effect $(P<0.05)$ on total aboveground biomass (TB). Mean TB increased in the order: control $(8765 \pm 4788 \mathrm{~kg})$, biosolids $(12,069 \pm 4896 \mathrm{~kg}), \mathrm{OMF}_{10}(14638 \pm 4769 \mathrm{~kg}), \mathrm{OMF}_{15}$ $(15,442 \pm 5363 \mathrm{~kg})$, and urea $(16176 \pm 4808 \mathrm{~kg})$, respectively. Total aboveground biomass increased with increasing $\mathrm{N}$ application rate $\left(\mathrm{TB}=9864+30.7 \mathrm{~N}_{\text {Rate }}, R^{2}=0.63, P=0.025\right.$, $\mathrm{SE}=4512)$. Differences in harvest indices between control $(51.5 \pm 4.71 \%)$ and treatments $(54.5 \pm 4.13 \%)$ were also significant in all crops $(P<0.05)$. There was a fertilizer type effect on harvest index $(P<0.05)$, but this was not observed in the first season (2006-2007). Harvest indices were generally higher at increasing $\mathrm{N}$ application rates $(P=0.04)$, except in the 20092010 crop $(P>0.05)$ due to drier conditions recorded in spring that year, and were also higher in first $(52.2-57.4 \%)$ compared with second wheat crops (46.5-50.7\%). Changes in TB due to fertilizer treatment were concurrent with changes in grain yield, and therefore harvest indices were not affected.

\section{Nitrogen Uptake and Nitrogen Use Efficiency}

Overall differences in NUE between-fertilizer types were significant $(P<0.05)$, and generally decreased in the order: urea $>$ $\mathrm{OMF}_{15} \geq \mathrm{OMF}_{10}>$ biosolids granules, respectively (Fig. 4). This suggested that $\mathrm{N}$ recovery in grain was affected by the concentration of (available) $\mathrm{N}$ in the fertilizer material. In the first crop, NUE was approximately 0.90 and $0.83 \times$ NUE urea for OMF and biosolids, respectively, averaged over the range of $\mathrm{N}$ application rates. In the second crop, these values were 0.77 and $0.54 \times$
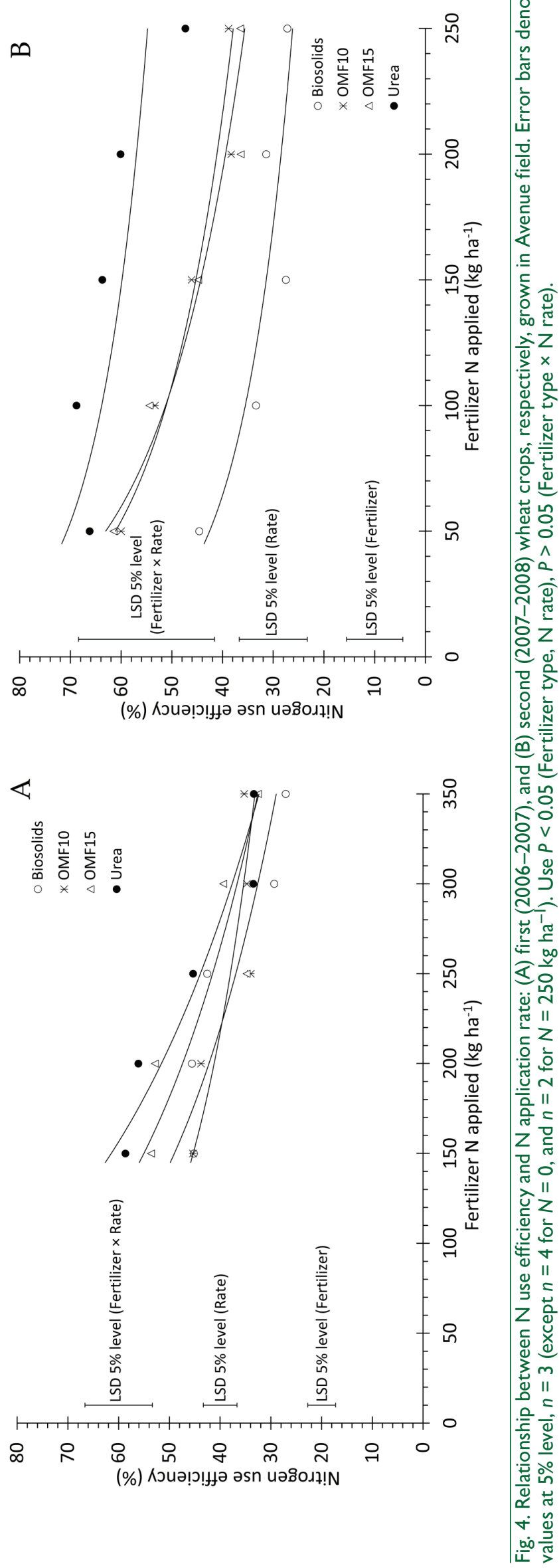


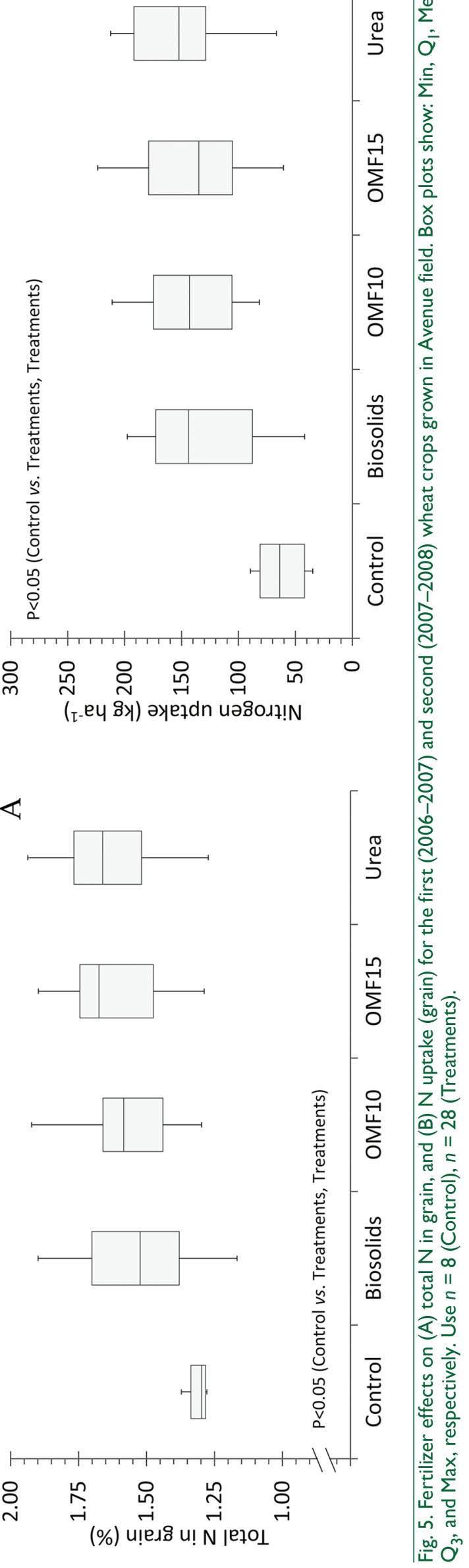

NUE urea for OMF and biosolids, respectively. Smaller differences in NUE between treatments in the first season (20062007) are attributed to the blanket fertilizer application (UAN at $100 \mathrm{~kg} \mathrm{ha}^{-1} \mathrm{~N}$ ) conducted in that crop.

Differences in NUE between treatments due to $\mathrm{N}$ uptake were also explained by both fertilizer effect on yield and total $\mathrm{N}$ in grain, as shown in Fig. $5(P<0.05)$. Total $\mathrm{N}$ in grain averaged across all crops were: $1.31 \pm 0.02 \%$ (control), $1.52 \pm 0.22 \%$ (biosolids), $1.57 \pm 0.16\left(\mathrm{OMF}_{10}\right), 1.60 \pm 0.19 \%\left(\mathrm{OMF}_{15}\right)$, and $1.64 \pm 0.18 \%$ (urea), respectively (LSD 5\% level: 0.04). There was a positive (linear) relationship between grain- $\mathrm{N}$ and $\mathrm{N}$ application rate $\left(\mathrm{N}_{\text {grain }}, \%=1.26+0.002 \mathrm{~N}_{\text {Rate }}, R^{2}=0.72\right.$, $P<0.001, \mathrm{SE}=0.1)$. This relationship may explain relatively lower grain-N contents in second $(1.45 \pm 0.13 \%)$ compared with first $(1.71 \pm 0.11 \%)$ wheat crops, which received the blanket application of $\mathrm{N}$ using $\mathrm{UAN}$ as noted earlier.

Agronomic efficiency (AE) was significantly different between fertilizer types $(P<0.05)$, with the exception of the first wheat crop in Avenue field $(P>0.05)$, and there was a similar trend to NUE (Fig. 6). Differences between $\mathrm{OMF}_{10}$ and $\mathrm{OMF}_{15}$ were relatively small, except in 2008-2009, which were about $20 \%$ on average over the $\mathrm{N}$ application rates used in these experiments. Based on responses shown in Fig. 4 and 7 , if fertilizers were to be applied at $\mathrm{N}$ rates equivalent to MERN (Table 5), average $\mathrm{N}$ recoveries and agronomic efficiencies would be approximately: $31 \%$ and $16 \mathrm{~kg} \mathrm{~kg}^{-1}$ (biosolids), $40 \%$ and $21 \mathrm{~kg} \mathrm{~kg}^{-1}\left(\mathrm{OMF}_{10}\right), 41 \%$ and $25 \mathrm{~kg} \mathrm{~kg}^{-1}\left(\mathrm{OMF}_{15}\right)$, and $52 \%$ and $29 \mathrm{~kg} \mathrm{~kg}^{-1}$ (urea), respectively, which are significantly different at a $10 \%$ probability level.

\section{Soil Chemistry}

Total nitrogen (TN) in soil increased by about $10 \%$ in fertilizer-treated plots compared with controls $(P<0.05)$ in both experiments. After $2 \mathrm{yr}$ of growing wheat, TN in the control plots changed little $(P>0.05)$, but differences were significant in Avenue field after the two extra years of growing grass $(P<$ $0.05)$. In Avenue field, there were also significant fertilizer type, $\mathrm{N}$ application rate, and fertilizer $\times \mathrm{N}$ rate effects on $\mathrm{TN}$ in soil $(P<0.05)$. Total $\mathrm{N}$ in soil was highest in biosolids- and lowest in urea-treated plots (Fig. 7a). When the experiment was terminated in 2010, TN levels in soil were similar in control and treatments $(P>0.05)$. This was attributed to an overall increase in soil organic matter (SOM) contents after the 2 yr growing grass. Despite this, there was a fertilizer type effect on TN in soil $(P<0.05)$ at the end of the grass phase, which was due to differences $(\approx 8 \%)$ between biosolids- and urea-treated plots, respectively. Fertilizer type effects were not seen $(P>0.05)$ in Chippies field after $2 \mathrm{yr}$ of wheat (Fig. $7 \mathrm{~b}$ ). Total $\mathrm{N}$ in soil increased linearly within the range of $\mathrm{N}$ application rates used at both sites $\left(R^{2} \geq 0.70, P<0.05\right)$.

In Avenue field, soil mineral nitrogen (SMN) levels before fertilizer application or residual SMN post-harvest were not affected by fertilizer type or rate $(P>0.05)$. The SMN values were consistently lower $(P<0.05)$ during the grass phase compared with the previous years under wheat. In this experiment, mean SMN levels were relatively low across all treatments and years, and did not exceed $8 \mathrm{mg} \mathrm{kg}^{-1}\left(\approx 20 \mathrm{~kg} \mathrm{ha}^{-1} \mathrm{~N}\right)$ in the 0 - to 200-mm soil depth. In Chippies field, there was a fertilizer type effect $(P=0.03)$ on SMN after wheat, but treatment differences 


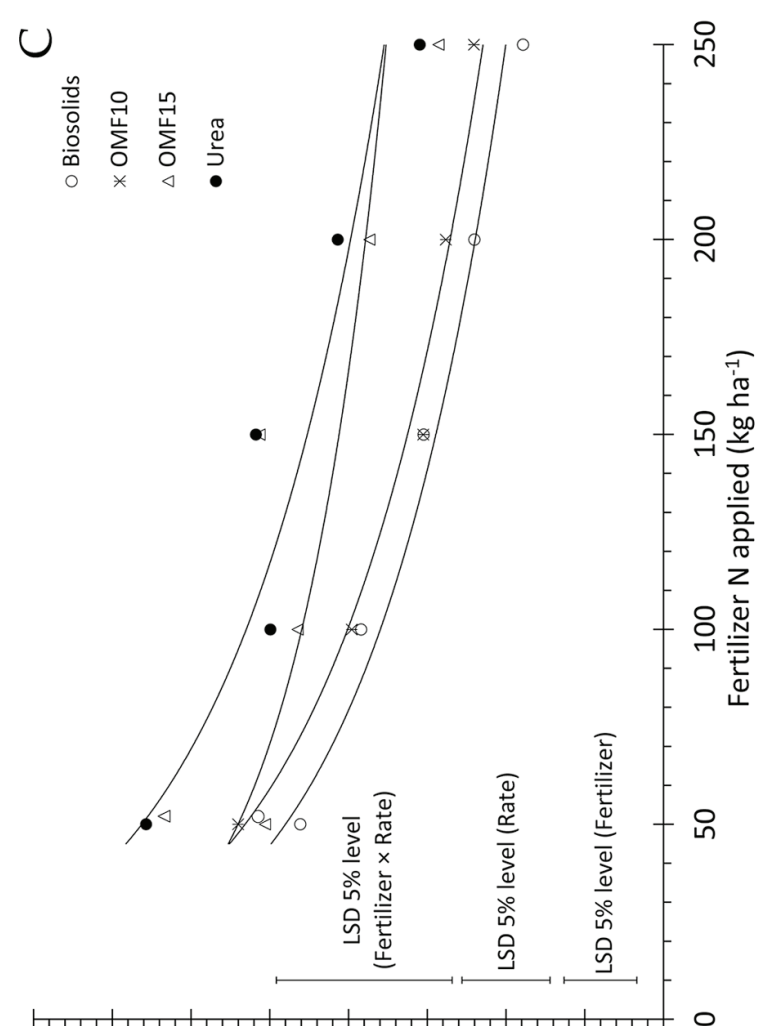

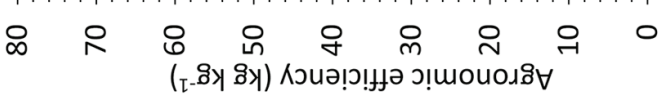

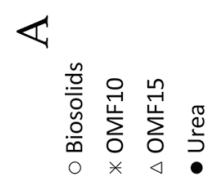

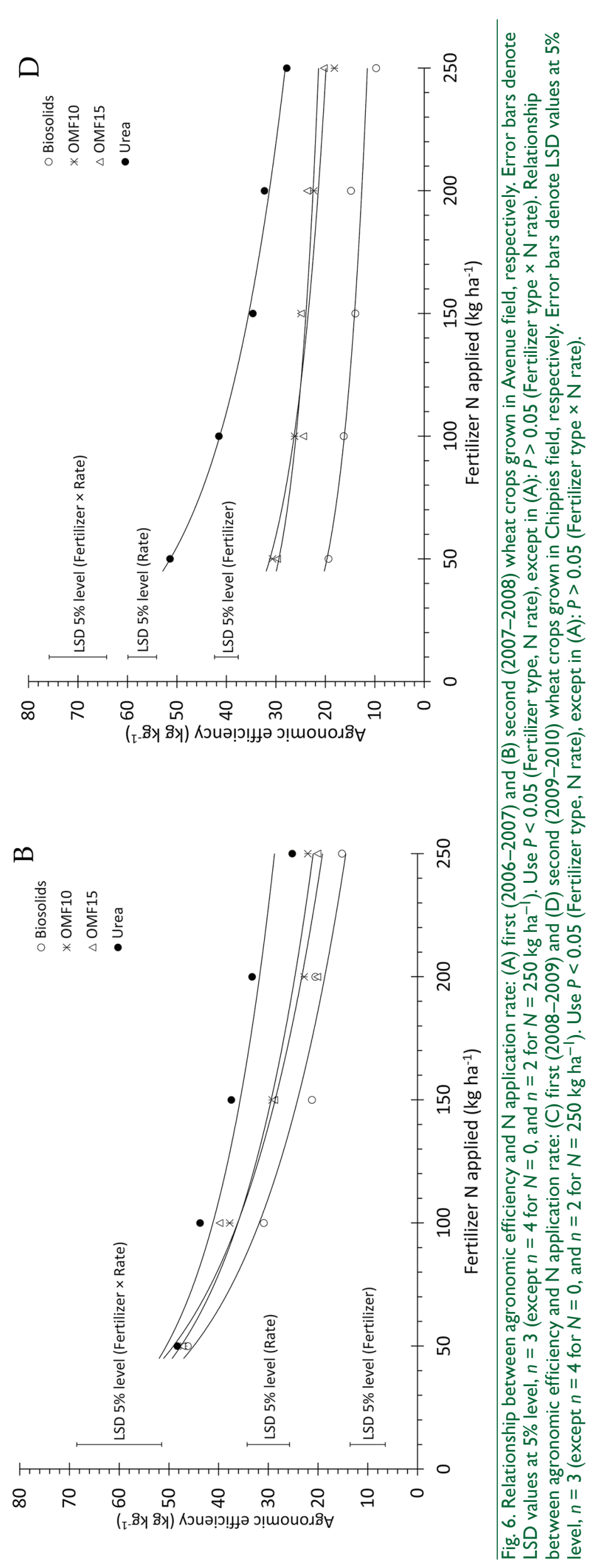

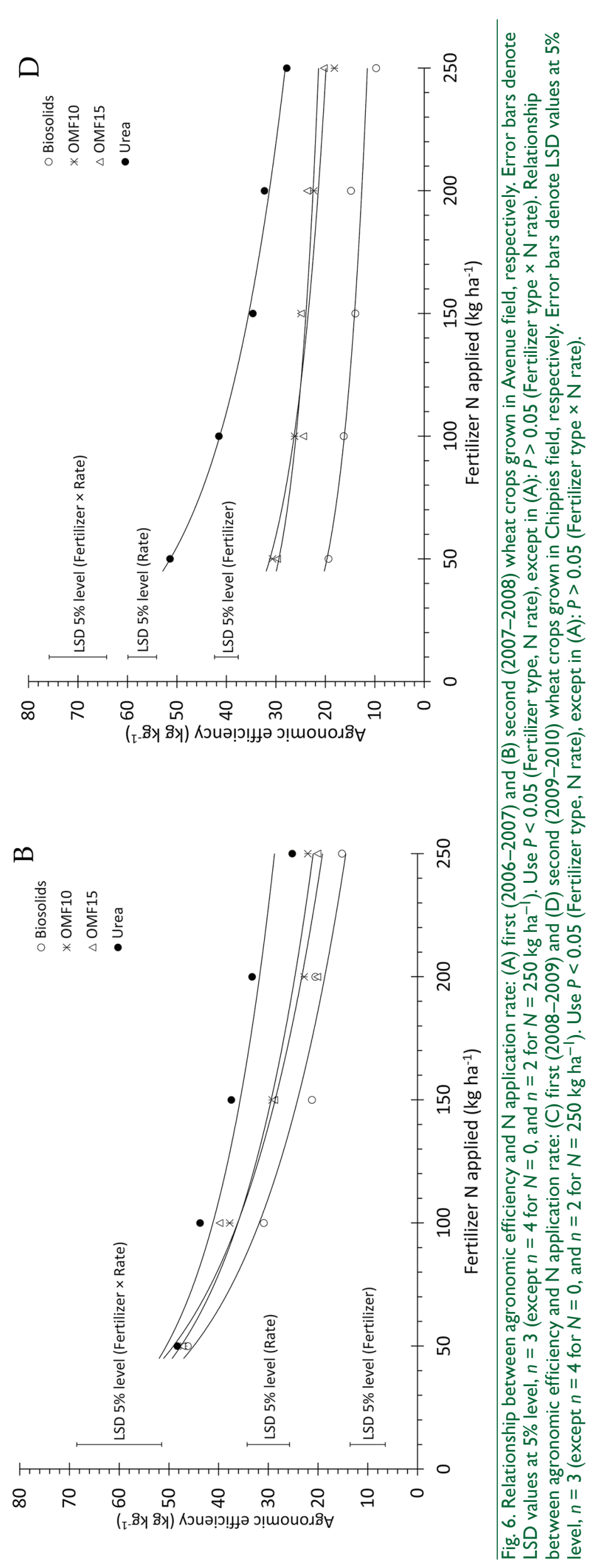

Agronomy Journal • Volume 109, Issue $2 \cdot 2017$
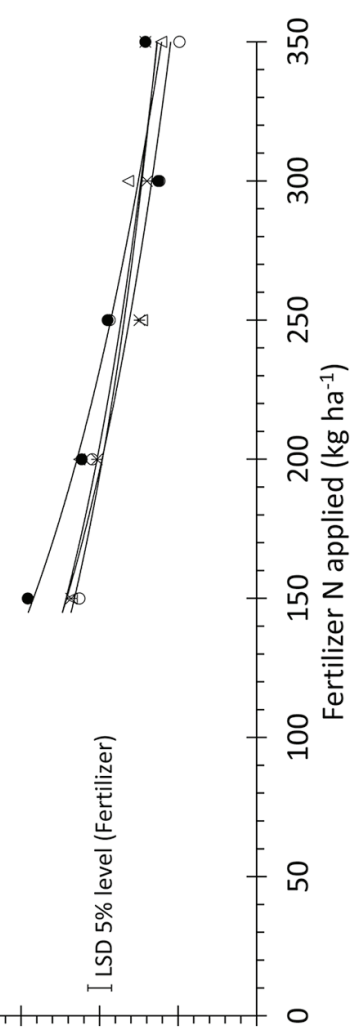

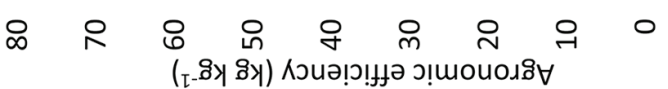


residual SMN associated with reduced $\mathrm{N}$ uptake under dry conditions in spring 2010, and was consistent with use-efficiency calculations, particularly in urea- and OMF-treated plots applied at $\geq 200 \mathrm{~kg} \mathrm{ha}^{-1} \mathrm{~N}$. Mean SMN values in those treatments were between 18 and $25 \mathrm{mg} \mathrm{kg}^{-1}\left(\approx 4565 \mathrm{~kg} \mathrm{ha}^{-1} \mathrm{~N}\right)$ compared to less than $7 \mathrm{mg} \mathrm{kg}^{-1}\left(\approx 18 \mathrm{~kg} \mathrm{ha}^{-1} \mathrm{~N}\right)$ in control and biosolidstreated soils, respectively.

Soil P Indices were unchanged throughout both experiments. In Avenue field there was a fertilizer-type effect $(P<$ $0.05)$, which was due to a small build-up of soil extractable $P$ in biosolids-treated plots within the range of values for the $\mathrm{P}$ Index (Fig. 8A). Soil extractable P remained close to constant in OMF-treated plots, but it showed a small decrease with urea compared with pre-experiment levels. In Chippies field, relative changes in soil extractable $P$ between fertilizer treatments were not significant $(P>0.05)$ (Fig. 8B).

In Avenue field, there was a fertilizer-type effect $(P<0.05)$ on soil extractable K levels after 4 yr (Fig. 9). During the 2 yr of wheat, soil extractable K levels changed little in biosolidsand urea-treated soils, but increased where OMF was applied compared with pre-experiment levels. Soil K Index remained unchanged at a value of 3 in all treatments, which was the index recorded prior to the experiment. This was possibly due to straw incorporation through cultivation following harvest of wheat crops and subsequent release of $\mathrm{K}$ to the soil (Lupwayi et al., 2006). Soil extractable K decreased significantly $(P<$ $0.05)$ from K Index 3 to $2+$ in fertilized plots after 2 yr of grass. There was an $\mathrm{N}$ rate effect on soil extractable $\mathrm{K}$ levels $(P<$ $0.05)$ when grass was grown on OMF- and urea-treated plots fertilized at $250 \mathrm{~kg} \mathrm{ha}^{-1} \mathrm{~N}$, in which soil K levels decreased to greater extent than on controls and with biosolids, respectively.

Overall, there were no significant differences $(P>0.05)$ in heavy metals in soil between control and treatments (Fig. 10). Although small, changes in $\mathrm{Pb}$ due to fertilizer rate were significant in plots treated with $250 \mathrm{~kg} \mathrm{ha}^{-1} \mathrm{~N}$, and the effect was only observed after 4 yr $(P<0.05)$. Mean values of total $\mathrm{Pb}$ for control and treatments $\left(N=250 \mathrm{~kg} \mathrm{ha}^{-1}\right)$ were 16.7 and $21.4 \mathrm{ug} \mathrm{kg}^{-1}$, respectively (LSD 5\% level: 2.8 ). These changes could not be explained by changes in soil $\mathrm{pH}$ (e.g., Singh and Narwal, 1984), which was relatively constant $(7.10 \pm 0.12)$ throughout the experiment.

Soil organic matter (SOM) was also measured at both experimental sites, but differences between control and treatments were not observed $(P>0.05)$. In Avenue field, mean SOM was higher at the end of the grass phase $(\approx 4.25 \%)$ compared with pre-experiment levels or during the wheat phase $(\approx 3.85 \%)$, respectively (LSD 5\% level: 0.02). Qualitative assessment of changes in SOM fractions as affected by $\mathrm{N}$ fertilization also warrants investigation (e.g., Hoffmann et al., 2006).

\section{DISCUSSION}

\section{Fertilizer Application Effects on Crop}

The two main yield components in wheat are number and weight of grains (Slafer, 2003). Number of grains per $\mathrm{m}^{2}$ is fixed by the size of the canopy, and weight of grains is affected by crop $\times$ environment interactions postanthesis, which determine the rate and duration of the grain-filling phase (Slafer, 2007). In the absence of water stress, increased yield potential is positively 
correlated with number of grains per $\mathrm{m}^{2}$ that result from increased number of grains per spike (Slafer and Andrade, 1993). Yield potential is also positively correlated with aboveground biomass (Foulkes et al., 2007) so that higher grain yields are realized in crops that accumulate greater biomass at maturity (Austin, 1982). Total aboveground biomass at maturity and TGW within this study showed differences between fertilizer treatments, which therefore explain differences in grain yield. Both yield components reflect crop's sensitivity to management (fertilizer type and quality, timing of application) and environmental factors (spring rainfall). The critical period for determination of grain yield in wheat is before anthesis (Fischer, 2011). Under equal conditions of water and radiation (plus temperature), crop yield may be simplified to be a function of nutrients supply both from soil and applied fertilizer, particularly N. Nutritional stresses, such as suboptimal N supply, will affect survival of florets and consequently number of grains, but it will also affect radiation use efficiency due to reduced interception by crop biomass (Abbate et al., 1995). Differences in $\mathrm{N}$ supply between fertilizer types (Antille et al., 2014c) were in agreement with treatment effects on aboveground biomass and ears numbers (number of grains) thereby influencing grain yield. Fertilizer type and $\mathrm{N}$ rate effects on ears per $\mathrm{m}^{2}$ were observed in all seasons, with the exception of 2006-2007 (Avenue field) in which treatment effects were largely offset by application of UAN in early spring.

Grain yield and yield components increased in the order: biosolids $>\mathrm{OMF}_{10}>\mathrm{OMF}_{15}>$ urea, which suggested sensitivity of crop performance to the readily available $\mathrm{N}$ supply in the fertilizer used and the pattern of $\mathrm{N}$ release following soil application. Such a response also suggested that fertilizer $\mathrm{N}$-related stresses prior to anthesis occurred to lesser extent in urea- and OMF- compared with biosolids-treated crop. This is because of faster $\mathrm{N}$ release and enhanced uptake in those treatments (Antille et al., 2013b, 2014a) following fertilizer application in spring, with subsequent $\mathrm{N}$ remobilization at later stages of crop development. Poorer physical properties

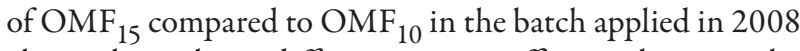
also explain relative differences in use-efficiency between the two materials (Jensen and Pesek, 1962). Therefore, improved quality control is a key requirement for mechanized application of OMF, as fine particles $(<1.00 \mathrm{~mm})$ are often the fraction responsible for high coefficient of variation (CV) during broadcast spreading (Hoffmeister et al., 1964; Hofstee and Huisman, 1990). Reduced fertilizer use efficiency and financial losses due to uneven fertilizer application become significant when CV exceeds about $10 \%$, considered to be the target value for disc type spreaders (Miller et al., 2009).

Harvest indices of fertilized crops observed in these experiments (range: 47.1-59.6\%) were comparable to those reported in the literature (range: 49.0-53.9\%) for other U.K. (e.g., White and Wilson, 2006) and international studies (e.g., Sinclair, 1998; Dai et al., 2016) using modern wheat cultivars. Seasonal effects of rainfall had a significant influence on harvest index due to the impact of drought (spring 2010) on ears per $\mathrm{m}^{2}$ (number of grains), but also because of shorter duration of the grain-filling phase that year. This latter effect explains significantly lower TGW ( $\approx 20 \%)$ in the 2010 harvest compared with previous years, which had more rainfall and cooler temperatures during June and July (Fig. 1). Drier soil conditions would also slow down
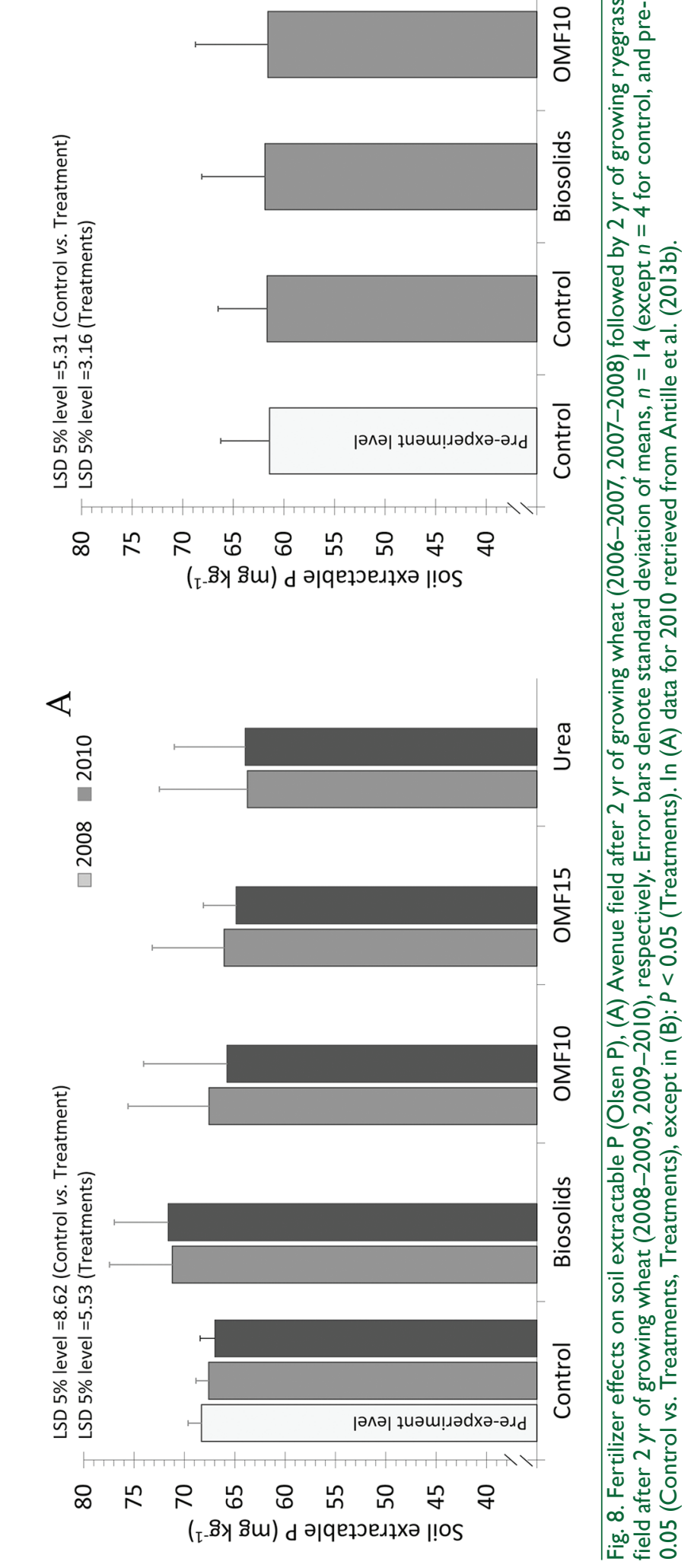


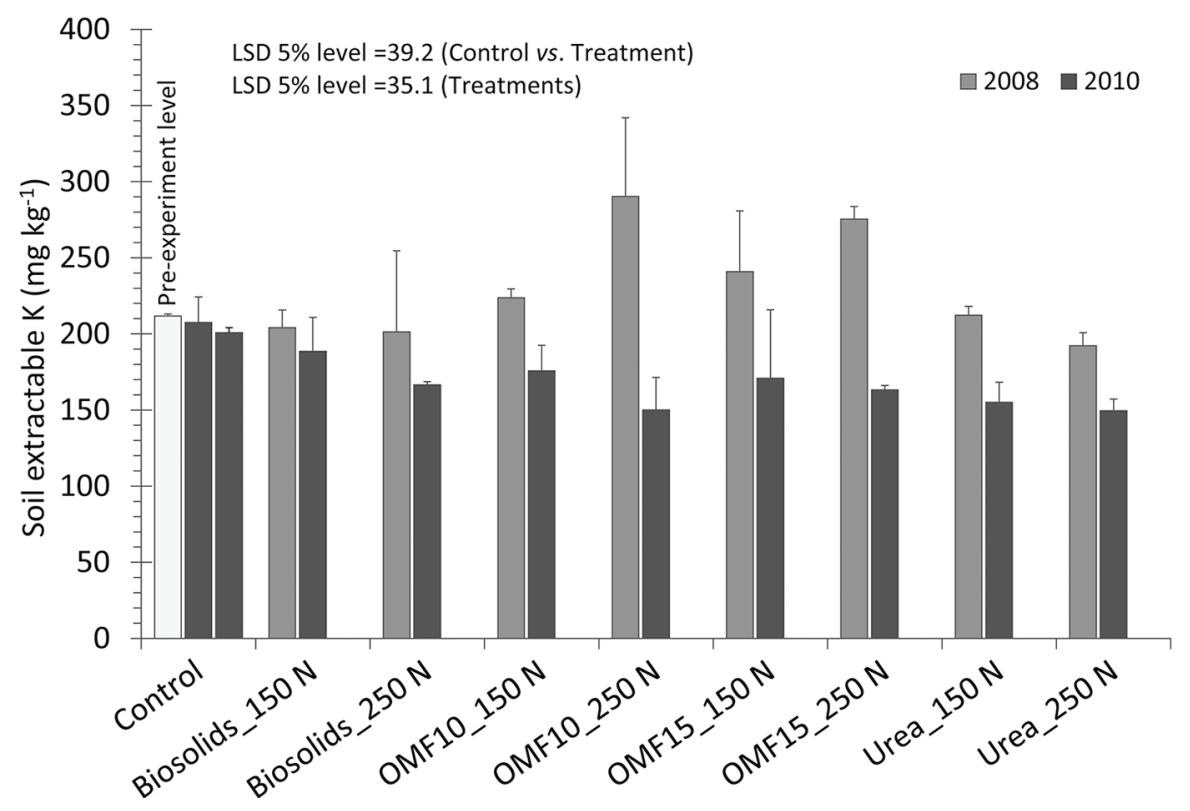

Fig. 9. Fertilizer effects on soil extractable K (Avenue field) after 2 yr of growing wheat (2006-2007, 2007-2008) followed by 2 yr of growing ryegrass (2009-2010). Error bars denote standard deviation of means, $n=3$ (except $n=4$ for control, and pre-experiment levels, $n=2$ when $N=250 \mathrm{~kg} \mathrm{ha}^{-1}$ ). Use $P>0.05$ (Control vs. Treatments), $P<0.05$ (Treatments, Fertilizer rate).

mineralization of organic $\mathrm{N}$ in the fertilizer applied thereby affecting the rate of nitrate- $\mathrm{N}$ supply to the crop to greater extent with biosolids than with OMF. Co-limitation of rainfall and $\mathrm{N}$ supply to the crop affected the AE of $\mathrm{N}$ applied as fertilizer and yield potential, also shown by other researchers (e.g., Slafer and Rawson, 1994; Sadras and Rodriguez, 2010). Larger accumulation of grain $\mathrm{N}$ in $\mathrm{OMF}_{15}$ and urea treatments (Fig. 5) was consistent with grain yield, harvest index, and NUE in those treatments. Increasing both grain yield and harvest index without compromising $\mathrm{N}$ content in grain requires a concurrent increase in crop-N accumulation (Sinclair, 1998). For OMF, $\mathrm{AE}$ and grain- $\mathrm{N}$ recoveries were also higher than those reported in the literature for biosolids N (e.g., Barbarick and Ippolito, 2000). For urea N, such values were within the range or higher compared with synthetic $\mathrm{N}$ fertilizers applied at similar rates $\left(\leq 300 \mathrm{~kg} \mathrm{ha}^{-1}\right)$ in spring to winter wheat crops in England (e.g., Macdonald et al., 1997; Sylvester-Bradley et al., 2014).

Linear relationships between grain- $\mathrm{N}$ content and $\mathrm{N}$ application rate were also reported by Benzian and Lane $(1979,1981)$ from long-term studies in Southeast England, albeit over a lower range of $\mathrm{N}$ application rates $\left(\leq 175 \mathrm{~kg} \mathrm{ha}^{-1}\right)$ and after excluding data denoting dilution effects at very small applications of N. Grain-N contents observed within this study were lower than the $2 \%$ target value recommended for British feedwheat varieties (DEFRA, 2010). This reflects difficulties in simultaneously increasing $\mathrm{N}$ recovery in grain and grain yield (Barraclough et al., 2010), particularly for single $\mathrm{N}$ applications. High levels of grain yield (e.g., first wheat crops, this study) are known to dilute $\mathrm{N}$ concentration in grain (Benzian et al., 1983). Environmental factors greatly influencing preanthesis accumulation of $\mathrm{N}$ (e.g., drought during spring of second wheat crops) and subsequent remobilization of $\mathrm{N}$ as the crop approaches the grain-filling phase (Gaju et al., 2014) may also explain lower grain $\mathrm{N}$ than that recommended for British feed- wheat. The linear relationships described above indicated that on average about $40 \mathrm{~kg} \mathrm{ha}^{-1} \mathrm{~N}$ added are needed to increase grain- $\mathrm{N}$ concentrations by $\approx 0.07 \%$ with $\mathrm{OMF}$ and urea, and by $\approx 0.05 \%$ with biosolids. These responses were lower than that reported in Benzian et al. (1983) from experiments in England and Belgium, which showed $\approx 40 \mathrm{~kg}$ of added $\mathrm{N}$ needed to increase grain- $\mathrm{N}$ concentrations by $0.1 \%$ for $\mathrm{N}$ application rates up to $200 \mathrm{~kg} \mathrm{ha}^{-1}$ using synthetic $\mathrm{N}$ fertilizers.

\section{Fertilizer Nitrogen Management}

Current agronomic recommendations for winter wheat (DEFRA, 2010) suggest that an application of $\mathrm{N}$ fertilizer at rates $\geq 120 \mathrm{~kg} \mathrm{ha}^{-1}$ is split into two dressings: at tillering (late February-mid-March), and the balance during early stem extension, typically early April (crop stages 30-31). When the balance is $\geq 120 \mathrm{~kg} \mathrm{ha}^{-1} \mathrm{~N}$, this needs to be split into two applications, as follows: $\approx 50 \%$ in early stem extension, and the remaining amount approximately 2 wk later (crop stage 32), but not after early May. These recommendations should be also observed when OMF is used in winter wheat production under the U.K. conditions. The MERN calculations (Table 5) showed that, on average, optimum fertilizer-N rates were between 225 and $260 \mathrm{~kg} \mathrm{ha}^{-1}$, depending on fertilizer type. For urea, average MERN was in agreement with the range reported in Welsh et al. (2003) for ammonium nitrate $\left(200-250 \mathrm{~kg} \mathrm{ha}^{-1} \mathrm{~N}\right)$, although derived from lower price ratios $\left(P_{R} \approx 3\right.$ to 4$)$ as recorded in the early 2000s (James and Godwin, 2003). Based on yield-to- $\mathrm{N}$ responses in the first season (2006-2007), the logistics of applying a mineral $\mathrm{N}$ source as the first and OMF as the second fertilizer application should be considered. A readily available $\mathrm{N}$ fertilizer source applied at tillering would increase leaf area index required to maximize light interception and yield (Abbate et al., 1995). Thus, it is suggested that 40 to $50 \%$ of the full (MERN) rate is applied at tillering (first application) using a straight $\mathrm{N}$ source and the remaining 50 to $60 \%$ as the second application using OMF, approximately $30 \mathrm{~d}$ later. Given that grain-N contents were below target in all crops, a further $\mathrm{N}$ application may be required. This may be with foliar urea or UAN at milk development (growth stage 71-75) not later 


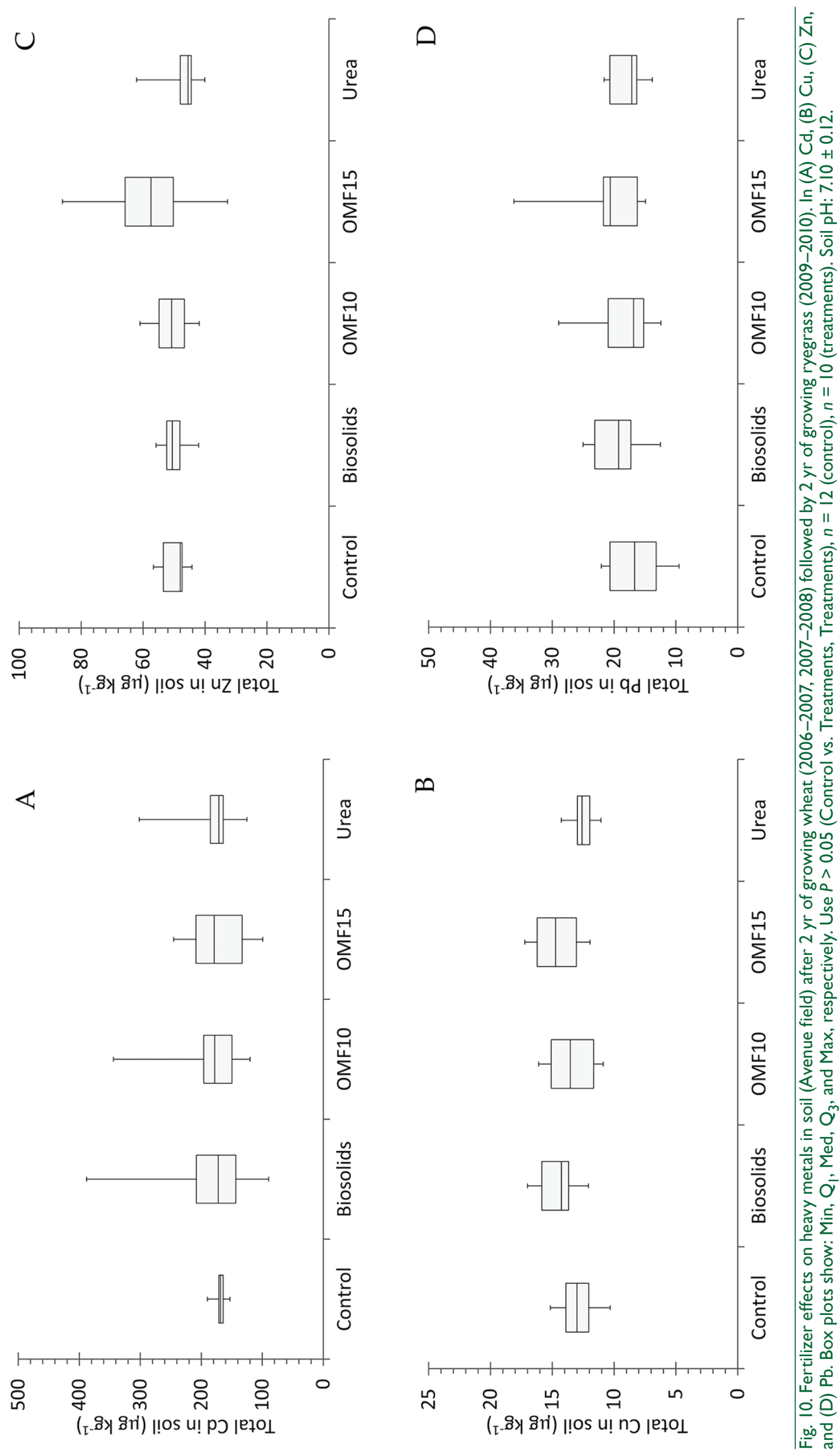


than early July, or solid $\mathrm{N}$ applied to soil when flag leaf is visible (growth stage 37) around late May to early June (Tottman et al., 1979). This latter option may have an effect on grain yield provided rainfall was not limiting. These recommendations require validation from longer-term studies.

\section{Fertilizer Application Effects on Soil}

A build-up of total $\mathrm{N}$ in soil (TN) was found in fertilized compared to non-fertilized soil, which was dependent on fertilizer type and rate. This observation was consistent with data derived from long-term $\mathrm{N}$ fertilization experiments on winter wheat (e.g., Halvorson et al., 1999). In cereal cropping systems in which crop residues are returned to soil, SOC and TN in soil often correlate well with aboveground biomass production (Blair et al., 2006). Total aboveground biomass within this study was positively correlated with fertilizer rate and crop residues would be incorporated through tillage ( $\approx 150$-mm deep) or left on the surface in the wheat and grass phases, respectively, which therefore support the above observations. The fertilizer type effect showed that TN in soil generally increased in the order: biosolids granules > OMF > urea, and was consistent with previous OMF studies in the glasshouse (Antille et al., 2014a). The degree of stabilization of organic- $\mathrm{N}$ fractions in biosolids and OMF coupled with lower $\mathrm{N}$ recovery in the crop compared with urea (Fig. 4 and 6) explains this effect, and agrees with observations made in similar studies (e.g., Tejada et al., 2002; Rigby et al., 2016).

The establishment of grass leys is known to be effective in restoring SOM levels following long-term arable rotation (Fullen and Booth, 2006). This explains higher SOM and similar TN levels in control and treatments in Avenue field after the grass phase. Following soil application, OMF requires an accumulated thermal time of $\approx 2500$ degree-days to mineralize approximately 70 to $80 \%$ of total OMF N (Antille et al., 2014c). Relatively slow $\mathrm{N}$ release from OMF suggests sustained $\mathrm{N}$ uptake by the crop during the growing season, and explains consistently low SMN recorded after the harvest of wheat, except when $\mathrm{N}$ uptake was restricted by rainfall as highlighted for the 2009-2010 season.

A small increase in soil extractable $\mathrm{P}$ was observed in biosolids-treated plots, but changed little in OMF-treated plots and declined a little where urea was used. These observations: (i) support the rationale behind the proposed OMF formulations, that was, to ensure that soil application of OMF would replenish, but not exceed P offtake by crops when applied at the optimum $\mathrm{N}$ rate (Antille, 2011; Antille et al., 2013c); (ii) reinforce the requirement for balanced fertilizer's $\mathrm{N} / \mathrm{P}$ ratio, particularly when OMF applications are based on crop $\mathrm{N}$ requirements and to soils with already satisfactory P status; and (iii) confirm the original hypothesis that soil application of OMF would have little effect on soil extractable P.

While acknowledging that $\mathrm{P}$ fertilization in soils with satisfactory $\mathrm{P}$ status (Olsen $\mathrm{P} \geq 25 \mathrm{mg} \mathrm{L}^{-1}$ or $\geq$ Index 3 ) may be omitted in some years (Shober and Sims, 2003; DEFRA, 2010; Poulton et al., 2013), soil application of OMF in these circumstances may be still technically viable provided crop $P$ requirements over the rotation cycle are not exceeded. The $\mathrm{OMF}_{15}$ formulation is more suitable than $\mathrm{OMF}_{10}$ for high $\mathrm{P}$ Index soil because of relatively wider N/P ratio. A straight $\mathrm{N}$ source may be used as part of the fertilization strategy to supply the balance of $\mathrm{N}$ when crop $\mathrm{P}$ requirements were to be met with OMF. High P Index soils (e.g., $\geq 3$ ) are common in areas near wastewater treatment sites (Skinner and Todd, 1998; Oliver et al., 2006) because of historical large applications of sludge. In those soils care must be exercised not to apply OMF if there was an inherent risk of $\mathrm{P}$ transfer to water courses such as in eroded soil, in runoff or through drainage, and within hydrologically connected areas. This observation is consistent with studies dealing with land application of biosolids (e.g., Pote et al., 1996; Haygarth et al., 1999; Elliott et al., 2005). Despite this, dissolved reactive phosphorus (DRP) concentrations in runoff are dependent on techniques used for $\mathrm{P}$ removal during the wastewater treatment process (Sibbesen and Sharpley, 1997). For example, the risk of increased DRP in runoff may be lower if $\mathrm{P}$ removal was chemical (e.g., precipitation with Fe) rather than biological (Penn and Sims, 2002). Biosolids used to produce OMF for this study had undergone chemical treatment. Precipitation of $\mathrm{P}$ with $\mathrm{FeCl}_{3}$ produces $\mathrm{Fe}$-phosphate compounds, which have low phytoavailability (Hogan et al., 2001; O'Connor et al., 2004). An earlier study by Antille et al. (2014b) showed that relative extractability (Leytem et al., 2004) of OMF P was between 3 and 12\%, which suggested only a small proportion of total $\mathrm{P}$ applied as OMF is released in plant-available form (Olsen $\mathrm{P}$ ) within the first season. The remaining OMF P may be released over several years following soil application, as shown in related studies involving biosolids P (e.g., Kelling et al., 1977; Vaneeckhaute et al., 2016). The slow release rate of OMF P may provide greater opportunities for improved crop uptake. Due to the crop response and soil behavior of OMF, growers in areas near production sites may be able to meet nutrient requirements of crops with relatively less reliance on synthetic $\mathrm{N}$ fertilizers. This may also assist the wastewater industry in meeting recycling targets within the existing land bank. Improved application techniques (e.g., soil incorporation for in-crop season application) will mitigate environmental concerns (e.g., runoff, gaseous emissions), and enhance nutrient use efficiency.

Soil incorporation of winter wheat stubbles after harvest maintained soil extractable K levels in urea- and biosolids-treated plots. Increased soil extractable K within OMF plots with $250 \mathrm{~kg} \mathrm{ha}^{-1}$ $\mathrm{N}$ suggested that $\mathrm{K}$ was applied in excess of crop requirements. There was an overall decline in soil $\mathrm{K}$ Index after growing grass for $2 \mathrm{yr}$ from $\mathrm{K}$ Index 3 to $2+$. The greater uptake of $\mathrm{K}$ where $\mathrm{N}$ is applied (Talibudeen et al., 1976) explains the lower soil K levels at the highest $\mathrm{N}$ rate used (Fig. 9) as well as improved fertilizer-N response in OMF and urea treatments compared with biosolids. Adequate supply of $\mathrm{K}$ and maintenance of soil extractable $\mathrm{K}$ are known to enhance fertilizer-N uptake and use efficiency (Aulakh and Malhi, 2005). Replacement of K offtake may not be sufficient to prevent long-term decline of soil extractable $\mathrm{K}$ and therefore additional K inputs may be needed (Heming, 2004), particularly in lighter soils (Arnold and Shepherd, 1990), and when rotations include both arable and grass crops (Andrist-Rangel et al., 2007). Fertilization with complex and compound fertilizers has shown enhanced nutrient uptake and increased crop yield compared with blended fertilizers (e.g., Schoeningh, 1994). This suggests that OMFs, as used in this study, may have a better AE than materials produced by blending biosolids granules and mineral fertilizers with similar N/P/K ratios (e.g., Smith et al., 2015). Conversion of biosolids granules into compound NPK fertilizers is also preferred to blended materials to minimize adverse effects on crops derived from particle segregation during handling and spreading (e.g., Jensen and Pesek, 1962). 
Heavy metal contents in biosolids granules and OMF were below recommended limit values given in the Sewage Sludge Directive 86/278/EEC (Council of European Communities, 1986). For sludge intended for use in agriculture, Directive 86/278/EEC suggests the following limits: $<40(\mathrm{Cd}),<1750$ $(\mathrm{Cu}),<1200(\mathrm{~Pb})$, and $<4000(\mathrm{Zn}) \mathrm{mg} \mathrm{kg}^{-1}$ (dry solids), respectively (Council of European Communities, 1986). This compares with: 0.98 to $1.20(\mathrm{Cd}), 264$ to $329(\mathrm{Cu}), 90$ to $113(\mathrm{~Pb})$, and 422 to $493(\mathrm{Zn}) \mathrm{mg} \mathrm{kg}^{-1}$ (dry solids) in the materials used in this study (Antille et al., 2013c). These values were also in compliance with the U.K. Sludge (Use in Agriculture) Regulations 1989 (Statutory Instrument No.: 1263). Concentrations of all four measured heavy metals in soil were well below permissible concentrations outlined in the Revised Soil Code (MAFF, 1998) while input rates of heavy metals to soil in biosolids and OMF were also lower than maximum permitted rates of application (Nicholson et al., 2003). Based on this dataset, soil application of OMF does not pose a significant threat to the environment in regards to potential accumulation of heavy metals in soil and increased risk of transfer to the food change via crop uptake. However, further assessments would be required if fertilizerinduced changes (decrease) in soil $\mathrm{pH}$ were observed in the longer term because of associated effects on heavy metals availability in soil. Although soil $\mathrm{pH}$ remained near neutrality throughout the experiment, this is an important consideration given potential risk of soil acidification from long-term use of urea-based fertilizers (Bouman et al., 1995). Risk assessment frameworks for heavy metals relevant to land application of biosolids under northern European conditions have been developed (e.g., Clarke et al., 2016), and may be adopted to guide decision-making about using OMF in crop production.

\section{Economic Considerations}

Global demand for fertilizers (primary nutrients) is estimated to grow at $\approx 2 \%$ per year from 2014 to 2020 (FAO, 2015). Although global shortages of fertilizer during that period are unlikely, deficits in $\mathrm{N}$ and phosphate may be expected in western Europe (FAO, 2015). Consequently, reliance on imports for these nutrients could drive fertilizer prices upward. To some extent, volatility in fertilizer (and energy) prices, as shown by record price levels seen in 2008 (e.g., urea $\mathrm{N}: \approx \mathrm{GBP} 1$ per $\mathrm{kg}$, triple superphosphate: $\approx \mathrm{GBP} 690$ per t) (Prince et al., 2009), encouraged growers to look toward organic materials to meet crop nutrient requirements and maintain soil fertility. Such a context provides opportunities for OMF to increase or maintain profit margins by means of reduced fertilizer input costs.

An earlier work by Antille (2011) showed that if OMF was priced at $\approx$ GBP 0.15 per $\mathrm{kg} \mathrm{N}$ the gross margin of winter cereal crops treated with OMF would be approximately equal to that of a crop treated with urea, provided both fertilizer materials were applied at the optimum $\mathrm{N}$ rate. The analysis conducted in that previous study accounted for increased cost of field application of OMF compared with urea that results from the relative concentrations of $\mathrm{N}$ in the two materials. If OMF was to be priced at the equivalent price of urea $\mathrm{N}$, the wastewater industry would have to subsidize the product to compensate for the loss of income (yield penalty) relative to that typically perceived with a synthetic $\mathrm{N}$ source. Given the assumptions made in the analyses
(Antille, 2011) it would be still an economic proposition for the wastewater industry to do this when compared with the costs of other disposal options (e.g., landfill, incineration). On average, application of biosolids granules resulted in lower $Y_{\text {MERN }}$ compared with OMF even though the price of biosolids $\mathrm{N}$ was considered to be zero. Lower $Y_{\text {MERN }}$ coupled with increased cost of spreading of biosolids (by $\approx 40-50 \%$ ) would have a negative impact on crop's gross margin, which in the study of Antille (2011) was estimated to be up to 13 and 29\% lower than OMF and urea, respectively. Handling and spreading of a bulkier material such as biosolids also have implications on field-operating efficiency. This is an important practical consideration in situations where the window available for spreading of $\mathrm{N}$ is relatively narrow due to restricted field access in early spring (e.g., trafficability, weather conditions), which may affect timing of application and therefore fertilizer use efficiency.

\section{CONCLUSIONS}

The main conclusions derived from this research are:

1. Average grain yields of winter wheat treated with OMF were up to $25 \%$ higher than with biosolids granules (sewage sludge alone), but 20\% lower than with urea. Differences in grain yield and yield-to- $\mathrm{N}$ responses between treatments were due to relative patterns of $\mathrm{N}$ release from fertilizer applied to soil influencing $\mathrm{N}$ uptake, biomass accumulation, and partitioning. These observations confirmed the hypothesis which these experiments tested and were consistent with all measurements of crop yield components,

2. The agronomic performance of winter wheat treated with OMF may be optimized by applying a straight $\mathrm{N}$ fertilizer source as the first and OMF as the second fertilizer application, respectively. Thus, the full fertilizer rate required for the crop should be split into 40 to $50 \%$ in the first application using straight $\mathrm{N}$, and the balance with OMF in the second. Nitrogen application timings need to be consistent with current agronomic guidelines (DEFRA, 2010). The OMF alone applied at the optimum rate $\left(\approx 250 \mathrm{~kg} \mathrm{ha}^{-1} \mathrm{~N}\right)$ is a more reliable source of $\mathrm{N}$ than biosolids granules due to reduced inter-annual variability in grain yield, improved $\mathrm{N}$ uptake, and $\mathrm{N}$ recovery in grain. Strategies for improved NUE with OMF include: optimization of particle size and size distribution, improved uniformity of distribution during field spreading, and correct timing of application,

3. Extractable P increased a little in biosolids- and decreased in urea-treated soils, respectively. For OMF, changes in soil extractable $\mathrm{P}$ and soil $\mathrm{P}$ Index were not significant. Thus, OMF $P$ replaced, approximately, P offtake by the crop, which supports the choice of the proposed OMF formulations. Soil K Index was maintained when wheat was grown, but declined from 3 to $2+$ following growing grass for $2 \mathrm{yr}$. Due to the influence of $\mathrm{K}$ on NUE, additional application of $\mathrm{K}$ fertilizer may be required to maintain an appropriate soil K Index under grass. Therefore, the hypothesis that K levels would be maintained in soils fertilized with OMF was true for cereal, but not for grass cropping. Heavy metals in soil were below permissible concentrations in all treatments, and therefore there appears to be no risk of soil accumulation or transfer to the food chain due to crop uptake,

4. Conversion of sludge, largely regarded as waste, into valueadded OMFs offers advantages such as increased opportunities to meet long-term recycling targets in areas near wastewater 
treatment works at potentially lower cost compared with other disposal options. Growers located in those areas may apply OMF to meet $\mathrm{N}$ requirements of crops, and maintain overall fertility of soils, but without significant impacts on available forms of soil P. Such a development will enable improved resource use efficiency and will likely deliver tangible benefits both to growers and the wastewater industry. The coating technique for OMF is a key aspect of this development allowing for consistent fertilizer materials to be produced from sludge by adjusting $\mathrm{N} / \mathrm{P} / \mathrm{K}$ ratios to meet specific requirements for crop and soil. This also enables some of the limitations encountered with biosolids to be overcome thereby contributing to minimize environmental concerns and secure the agricultural route for recycling. From this, there appears to be potential for further development of OMF products.

\section{ACKNOWLEDGMENTS}

The authors are grateful to United Utilities Group PLC (Warrington, U.K.), The Engineering and Physical Science Research Council (Swindon, U.K.), and Cranfield University (Cranfield, U.K.) for technical, financial, and operational support to conduct this research. Help received from Dr. S.M. Le (formerly at United Utilities Group PLC), Dr. D.R. Chadwick (Bangor University, UK),P.H. Bellamy, R.J. Walker, and Dr. R. Andrews, and assistance from field and laboratory technical staff at Cranfield University is appreciated. Dr. R.A. Fischer (CSIRO Agriculture and Food, Australia) reviewed the manuscript and provided valuable comments.

\section{REFERENCES}

Abbate, P.E., F.H. Andrade, and J.P. Culot. 1995. The effects of radiation and nitrogen on number of grains in wheat. J. Agric. Sci. 124(3):351-360. doi:10.1017/S0021859600073317

Abraham, T.P., and V.Y. Rao. 1966. An investigation of functional models for fertilizer response surfaces. J. Indian Soc. Agric. Stat. 18(1):45-61.

Andrist-Rangel, Y., A.C. Edwards, S. Hillier, and I. Öborn. 2007. Long-term $\mathrm{K}$ dynamics in organic and conventional mixed cropping systems as related to management and soil properties. Agric. Ecosyst. Environ. 122(4):413-426. doi:10.1016/j. agee.2007.02.007

Antille, D.L. 2011. Formulation, utilisation and evaluation of organomineral fertilisers. Engineering Doctorate Diss. Cranfield Univ., Cranfield, UK.

Antille, D.L., D. Ansorge, M.L. Dresser, and R.J. Godwin. 2013a. Soil displacement and soil bulk density changes as affected by tire size. Trans. ASABE 56(5):1683-1693. doi:10.13031/trans.56.9886

Antille, D.L., L. Gallar, P.C.H. Miller, and R.J. Godwin. 2015. An investigation into the fertilizer particle dynamics off-the-disc. Appl. Eng. Agric. 31(1):49-60. doi:10.13031/aea.31.10729

Antille, D. L., R. Sakrabani, and R.J. Godwin. 2013b. Field-scale evaluation of biosolids-derived organomineral fertilisers applied to ryegrass (Lolium perenne L.) in England. Applied and Environ. Soil Sci., Vol.: 2013, Article 960629. doi:10.1155/2013/960629.

Antille, D.L., R. Sakrabani, and R.J. Godwin. 2014a. Effects of biosolids-derived organomineral fertilizers, urea and biosolids granules on crop and soil established with ryegrass (Lolium perenne L.). Commun. Soil Sci. Plant Anal. 45(12):1605-1621. doi:10.1080/0 0103624.2013.875205

Antille, D.L., R. Sakrabani, and R.J. Godwin. 2014b. Phosphorus release characteristics from biosolids-derived organomineral fertilisers. Commun. Soil Sci. Plant Anal. 45(19):2565-2576. doi: 10.1080/00103624.2014.912300
Antille, D.L., R. Sakrabani, and R.J. Godwin. 2014c. Nitrogen release characteristics from biosolids-derived organomineral fertilisers. Commun. Soil Sci. Plant Anal. 45(12):1687-1698. doi:10.1080/0 0103624.2014.907915

Antille, D. L., R. Sakrabani, S.F. Tyrrel, M.S. Le, R.J. Godwin. 2013c. Characterisation of organomineral fertilisers derived from nutrient-enriched biosolids granules. Applied and Environ. Soil Sci., Vol.: 2013, Article 694597. doi:10.1155/2013/694597.

Arnold, P.W., and M.A. Shepherd. 1990. Phosphorus and potassium requirements of cereals. Research Review no.: 16. Agric. and Horticulture Development Board, Kenilworth, UK. https://cereals.ahdb.org.uk/publications/1990/february/01/phosphorus-andpotassium-requirements-of-cereals.aspx (accessed 28 Jan. 2017).

ASAE Standards. 1999. SAE S.341.2: Procedure for measuring distribution uniformity and calibrating granular broadcast spreaders. ASAE, St. Joseph, MI.

Aulakh, M.S., and S.S. Malhi. 2005. Interactions of nitrogen with other nutrients and water: Effect on crop yield and quality, nutrient use efficiency, carbon sequestration, and environmental pollution. Adv. Agron. 86:341-409. doi:10.1016/ S0065-2113(05)86007-9

Austin, R.B. 1982. Crop characteristics and the potential yield of wheat. J. Agric. Sci. 98(2):447-453. doi:10.1017/ S002185960004199X

Baligar, V.C., N.K. Fageria, and Z.L. He. 2001. Nutrient use efficiency in plants. Commun. Soil Sci. Plant Anal. 32(7-8):921-950. doi:10.1081/CSS-100104098

Barbarick, K.A., and J.A. Ippolito. 2000. Nitrogen fertilizer equivalency of sewage biosolids applied to dryland winter wheat. J. Environ. Qual. 29(4):1345-1351. doi:10.2134/ jeq2000.00472425002900040043x

Barraclough, P.B., J.R. Howarth, J. Jones, R. Lopez-Bellido, S. Parmar, C.E. Shepherd, and M.J. Hawkesford. 2010. Nitrogen efficiency of wheat: Genotypic and environmental variation and prospects for improvement. Eur. J. Agron. 33(1):1-11. doi:10.1016/j. eja.2010.01.005

Bastian, R.K. 1997. The biosolids (sludge) treatment, beneficial use, and disposal situation in the USA. Eur. Water Pollut. Control $7(2): 62-79$.

Benzian, B., R.J. Darby, P. Lane, F.V. Widdowson, and L.M.J. Verstraeten. 1983. Relationship between $\mathrm{N}$ concentration of grain and grain yield in recent winter-wheat experiments in England and Belgium, some with large yields. J. Sci. Food Agric. 34(7):685695. doi:10.1002/jsfa.2740340704

Benzian, B., and P. Lane. 1979. Some relationships between grain yield and grain protein of wheat experiments in south-east England and comparisons with such relationships elsewhere. J. Sci. Food Agric. 30(1):59-70. doi:10.1002/jsfa.2740300111

Benzian, B., and P. Lane. 1981. Interrelationship between nitrogen concentration in grain, grain yield and added fertiliser nitrogen in wheat experiments of South-East England. J. Sci. Food Agric. 32(1):35-43. doi:10.1002/jsfa.2740320107

Blair, N., R.D. Faulkner, A.R. Till, and P.R. Poulton. 2006. Longterm management impacts on soil C, N and physical fertility: Part I: Broadbalk experiment. Soil Tillage Res. 91(1-2):30-38. doi:10.1016/j.still.2005.11.002

Bouman, O.T., D. Curtin, C.A. Campbell, V.O. Biederbeck, and H. Ukrainetz. 1995. Soil acidification from long-term use of anhydrous ammonia and urea. Soil Sci. Soc. Am. J. 59(5):1488-1494. doi:10.2136/sssaj1995.03615995005900050039x

British Standard. 1990. BS1377 Section 2.0:1990: Sedimentation by pipette method. The British Standards Inst., London.

British Standard. 1995a. BS7755 Section 3.8:1995: Soil quality. Chemical methods. Determination of organic and total carbon after dry combustion (elementary analysis). Equivalent to ISO10694:1995. The British Standards Inst., London. 
British Standard. 1995b. BS7755 Section 3.6:1995: Determination of phosphorus. Spectrometric determination of phosphorus soluble in sodium hydrogen carbonate solution. Equivalent to ISO11263:1994. The British Standards Inst., London.

British Standard. 1998. BS7755 Section 3.13:1998: Soil quality. Chemical methods. Determination of cadmium, chromium, cobalt, copper, lead, manganese, nickel and zinc in aqua regia extracts of soil. Flame and electrothermal atomic absorption spectrometric methods. Equivalent to ISO11047:1998. The British Standards Inst., London.

British Standard. 2001. BS-EN13654-2:2001: Soil improvers and growing media. Determination of nitrogen (Dumas method). Equivalent to ISO5725:1994. The British Standards Inst., London.

Chambers, B.J., F.A. Nicholson, M. Aitken, E. Cartmell, and C. Rowlands. 2003. Benefits of biosolids to soil quality and fertility. Water Environ. J. 17(3):162-167. doi:10.1111/j.1747-6593.2003. tb00455.x

Clarke, R.M., and E. Cummins. 2015. Evaluation of "classic" and emerging contaminants resulting from the application of biosolids to agricultural lands: A review. Hum. Ecol. Risk Assess. 21(2):492-513. doi:10.1080/10807039.2014.930295

Clarke, R., D. Peyton, M.G. Healy, O. Fenton, and E. Cummins. 2016. A quantitative risk assessment for metals in surface water following the application of biosolids to grassland. Sci. Total Environ. 566-567:102-112. doi:10.1016/j.scitotenv.2016.05.092

Council of European Communities. 1986. Council Directive of 12 June 1986 on the protection of the environment, and in particular of the soil, when sewage sludge is used in agriculture (Sewage Sludge Directive 86/278/EEC). Official J. European Community L181:6-12.

Cranfield University. 2010. Historic station data. Cranfield Univ., Silsoe Campus, UK.

Dai, J., B. Bean, B. Brown, W. Bruening, J. Edwards, M. Flowers et al. 2016. Harvest index and straw yield of five classes of wheat. Biomass Bioenergy 85:223-227. doi:10.1016/j.biombioe.2015.12.023

Dawson, C.J., and J. Hilton. 2011. Fertiliser availability in a resourcelimited world: Production and recycling of nitrogen and phosphorus. Food Policy 36(Suppl. 1):14-22. doi:10.1016/j. foodpol.2010.11.012

DEFRA. 2010. Fertiliser manual. Reference Book 209, 8th ed. Dep. for Environment, Food and Rural Affairs, London.

Delin, S. 2016. Fertilizer value of phosphorus in different residues. Soil Use Manage. 32(1):17-26. doi:10.1111/sum.12227

Diacono, M., and F. Montemurro. 2010. Long-term effects of organic amendments on soil fertility. A review. Agron. Sustain. Dev. 30(2):401-422. doi:10.1051/agro/2009040

Donald, C.M., and J. Hamblin. 1976. The biological yield and harvest index of cereals as agronomic and plant breeding criteria. Adv. Agron. 28:361-405. doi:10.1016/S0065-2113(08)60559-3

Dudka, S., and W.P. Miller. 1999. Accumulation of potentially toxic elements in plants and their transfer to human food chain. J. Environ. Sci. Health B 34(4):681-708. doi:10.1080/03601239909373221

Elliott, H.A., R.C. Brandt, and G.A. O'Connor. 2005. Runoff phosphorus losses from surface-applied biosolids. J. Environ. Qual. 34(5):1632-1639. doi:10.2134/jeq2004.0467

Elliott, H.A., G.A. O'Connor, P. Lu, and S. Brinton. 2002. Influence of water treatment residuals on phosphorus solubility and leaching. J. Environ. Qual. 31(4):1362-1369. doi:10.2134/jeq2002.1362

Evans, T., N. Lowe, and P. Matthews. 2004. Sustainable biosolidsWelcomed practice through community partnership and the consequential economic benefits. Water Sci. Technol. 49:241-249.

FAO. 2015. World fertilizer trends and outlook to 2018. Food and Agriculture Organization of the United Nations, Rome, Italy. http://www.fao.org/3/a-i4324e.pdf (accessed 27 Jan. 2017).
Fischer, R.A. 2008. The importance of grain or kernel number in wheat: A reply to Sinclair and Jamieson. Field Crops Res. 105(12):15-21. doi:10.1016/j.fcr.2007.04.002

Fischer, R.A. 2011. Wheat physiology: A review of recent developments. Crop Pasture Sci. 62(2):95-114. doi:10.1071/CP10344

Foulkes, M.J., J.W. Snape, V.J. Shearman, M.P. Reynolds, O. Gaju, and R. Sylvester-Bradley. 2007. Genetic progress in yield potential in wheat: Recent advances and future prospects. J. Agric. Sci. 145(1):17-29. doi:10.1017/S0021859607006740

Fullen, M.A., and C.A. Booth. 2006. Long term grass ley set aside on sandy soils: A case study. J. Soil Water Conserv. 61(4):236-241.

Gaju, O., V. Allard, P. Martre, J. Le Gouis, D. Moreau, M. Bogard et al. 2014. Nitrogen partitioning and remobilization in relation to leaf senescence, grain yield and grain nitrogen concentration in wheat cultivars. Field Crops Res. 155:213-223. doi:10.1016/j. fcr.2013.09.003

Hall, D.G.M., M.J. Reeve, A.J. Thomasson, and V.F. Wright. 1977. Water retention, porosity, and density of field soils. Technical Monogr. 9. The Soil Survey of England and Wales, Harpenden, UK.

Halvorson, A.D., C.A. Reule, and R.F. Follett. 1999. Nitrogen fertilization effects on soil carbon and nitrogen in a dryland cropping system. Soil Sci. Soc. Am. J. 63(4):912-917. doi:10.2136/ sssaj1999.634912x

Haygarth, P.M., A.L. Heathwaite, S.C. Jarvis, and T.R. Harrod. 1999. Hydrological factors for phosphorus transfer from agricultural soils. Adv. Agron. 69:153-178. doi:10.1016/ S0065-2113(08)60949-9

Heffer, P., and M. Prud'homme. 2013. Fertilizer outlook 2013-2017. In: Proceedings 81st International Fertilizer Industry Association Conference, Chicago, IL. May 2013. Paper no.: A/13/78. http:// www.fertilizer.org/ (accessed 27 Jan. 2017).

Heming, S.D. 2004. Potassium balances for arable soils in southern England 1986-1999. Soil Use Manage. 20(4):410-417. doi:10.1079/SUM2004273

Heming, S.D. 2007. Phosphorus balances for arable soils in Southern England 1986-1999. Soil Use Manage. 23(2):162-170. doi:10.1111/j.1475-2743.2006.00071.x

Higgs, B., A.E. Johnston, J.L. Salter, and C.J. Dawson. 2000. Some aspects of achieving sustainable phosphorus use in agriculture. J. Environ. Qual. 29(1):80-87. doi:10.2134/ jeq2000.00472425002900010010x

Hill, J. 2005. Recycling biosolids to pasture-based animal production systems in Australia: A review of evidence on the control of potentially toxic metals and persistent organic compounds recycled to agricultural land. Aust. J. Agric. Res. 56(8):753-773. doi:10.1071/ AR04264

Hoffmann, S., E. Schulz, G. Csitári, and L. Bankó. 2006. Influence of mineral and organic fertilizers on soil organic carbon pools. Arch. Agron. Soil Sci. 52(6):627-635. doi:10.1080/03650340601048652

Hoffmeister, G., S. C. Watkins, J. Silverberg. 1964. Fertilizer consistency, bulk blending of fertilizer material: Effect of size, shape and density on segregation. J. of Agric. and Food Chemistry 12(1): 64-69. doi: 10.1021/jf60131a020.

Hofstee, J. W., and W. Huisman. 1990. Handling and spreading of fertilizers: Part 1, Physical properties of fertilizer in relation to particle motion. J. Agric. Eng. Res. 47(4): 213-234. doi:10.1016/0021-8634(90)80043-T.

Hogan, F., M. McHugh, and S. Morton. 2001. Phosphorus availability for beneficial use in biosolids products. Environ. Technol. 22(11):1347-1353. doi:10.1080/09593332208618191 
James, I.T., and R.J. Godwin. 2003. Soil, water and yield relationships in developing strategies for the precision application of nitrogen fertiliser to winter barley. Biosystems Eng. 84(4):467-480. doi:10.1016/S1537-5110(02)00284-2

Jensen, D., and J. Pesek. 1962. Inefficiency of fertilizer use resulting from nonuniform spatial distribution: II. Yield losses under selected distribution patterns. Soil Sci. Soc. Am. J. 26(2):174-178. doi:10.2136/sssaj1962.03615995002600020023x

Johnston, A.E., P.R. Poulton, and R.P. White. 2013. Plant-available soil phosphorus. Part II: The response of arable crops to Olsen P on a sandy clay loam and a silty clay loam. Soil Use Manage. 29(1):1221. doi:10.1111/j.1475-2743.2012.00449.x

Johnston, A.E., P.R. Poulton, R.P. White, and A.J. Macdonald. 2016. Determining the longer term decline in plant-available soil phosphorus from short-term measured values. Soil Use Manage. 32(2):151-161. doi:10.1111/sum.12253

Kachanoski, R.G. 2009. Crop response to nitrogen fertilizer: The delta yield concept. Can. J. Soil Sci. 89(5):543-554. doi:10.4141/ CJSS09003

Kelessidis, A., and A.S. Stasinakis. 2012. Comparative study of the methods used for treatment and final disposal of sewage sludge in European countries. Waste Manag. 32(6):1186-1195. doi:10.1016/j.wasman.2012.01.012

Kelling, K.A., L.M. Walsh, and D.R. Keeney. 1977. A field study of the agricultural use of sewage sludge. II. Effect on soil $\mathrm{N}$ and P. J. Environ. Qual. 6(4):345-356. doi:10.2134/ jeq1977.00472425000600040003x

King, D.W. (1969). Soils of the Luton and Bedford districts: A reconnaissance survey. Special Survey no.1. The Soil Survey of England and Wales, Rothamsted, Harpenden, UK.

Lagae, H.J., M. Langemeier, D. Lybecker, and K. Barbarick. 2009. Economic value of biosolids in a semiarid agroecosystem. Agron. J. 101(4):933-939. doi:10.2134/agronj2008.0209x

Landry, H., C. Laguë, and J.M. Agnew. 2011. Mechanized land application of organic fertilizers: A review. In: K. Bundgaard and L. Isaksen, editors, Agriculture research and technology. Nova Science Publishers, Inc., Hauppauge, NY. p. 171-209.

Landry, H., F. Thirion, C. Laguë, and M. Roberge. 2006. Numerical modeling of the flow of organic fertilizers in land application equipment. Comput. Electron. Agric. 51(1-2):35-53. doi:10.1016/j.compag.2005.11.001

Leytem, A.B., J.T. Sims, and F.J. Coale. 2004. Determination of phosphorus source coefficients for organic phosphorus sources: Laboratory studies. J. Environ. Qual. 33(1):380-388. doi:10.2134/ jeq2004.3800

Lupwayi, N.Z., G.W. Clayton, J.T. O’Donovan, K.N. Harker, T.K. Turkington, and Y.K. Soon. 2006. Potassium release during decomposition of crop residues under conventional and zero tillage. Can. J. Soil Sci. 86(3):473-481. doi:10.4141/S05-049

Macdonald, A.J., P.R. Poulton, D.S. Powlson, and D.S. Jenkinson. 1997. Effects of season, soil type and cropping on recoveries, residues and losses of $15 \mathrm{~N}$-labelled fertilizer applied to arable crops in spring. J. Agric. Sci. 129(2):125-154. doi:10.1017/ S0021859697004619

MAFF. 1986. The analysis of agricultural materials. 3rd ed. Ministry of Agric., Fisheries, and Food, London.

MAFF. 1998. Code of good agricultural practice for the protection of soil (Revised, 1998). Ministry of Agric., Fisheries, and Food, London.

Milieu Ltd., WRc, Risk \& Policy Analysts Ltd. 2010. Environmental, economic and social impacts of the use of sewage sludge on land. Final Report, Part III: Project Interim Reports. DG Environment under Study Contract DG ENV.G4/ETU/2008/0076r. Milieu Ltd., Brussels, Belgium. http://ec.europa.eu/environment/ archives/waste/sludge/pdf/part_iii_report.pdf (accessed 27 Jan. 2017).
Miller, P.C.H., E. Audsley, and I.R. Richards. 2009. Costs and effects of uneven spreading of nitrogen fertilisers. Proceeding no. 659. The Int. Fertiliser Soc., York, UK.

Nicholson, F.A., S.R. Smith, B.J. Alloway, C. Carlton-Smith, and B.J. Chambers. 2003. An inventory of heavy metals inputs to agricultural soils in England and Wales. Sci. Total Environ. 311(13):205-219. doi:10.1016/S0048-9697(03)00139-6

Nix, J. 2010. Farm management pocketbook. 40th ed. Imperial College of London at Wye, London.

O'Connor, G.A., D. Sarkar, S.R. Brinton, H.A. Elliot, and F.G. Martin. 2004. Phytoavailability of biosolids phosphorus. J. Environ. Qual. 33(2):703-712. doi:10.2134/jeq2004.7030

Oliver, M.A., J.R. Archer, S.J. Baxter, A.D. Todd, and R.J. Skinner. 2006. The representative soil sampling scheme of England and Wales: A statistical analysis of topsoil nutrient status and $\mathrm{pH}$ between 1971 and 2001. Soil Use Manage. 22(4):372-382. doi:10.1111/j.1475-2743.2006.00051.x

Olsen, S.R., C.V. Cole, F.S. Watanabe, and L.A. Dean. 1954. Estimation of available phosphorus in soils by extraction with sodium bicarbonate. USDA Circular no.: 939. USDA, Washington, DC.

Penn, C.J., and J.T. Sims. 2002. Phosphorus forms in biosolidsamended soils and losses in runoff. J. Environ. Qual. 31(4):13491361. doi:10.2134/jeq2002.1349

Pote, D.H., T.C. Daniel, P.A. Moore, D.J. Nichols, A.N. Sharpley, and D.R. Edwards. 1996. Relating extractable soil phosphorus to phosphorus losses in runoff. Soil Sci. Soc. Am. J. 60(3):855-859. doi:10.2136/sssaj1996.03615995006000030025x

Poulton, P.R., A.E. Johnston, and R.P. White. 2013. Plant-available soil phosphorus. Part I: The response of winter wheat and spring barley to Olsen P on a silty clay loam. Soil Use Manage. 29(1):4-11. doi:10.1111/j.1475-2743.2012.00450.x

Powlson, D.S., A. Bhogal, B.J. Chambers, K. Coleman, A.J. Macdonald, K.W.T. Goulding, and A.P. Whitmore. 2012. The potential to increase soil carbon stocks through reduced tillage or organic material additions in England and Wales: A case study. Agric. Ecosyst. Environ. 146(1):23-33. doi:10.1016/j.agee.2011.10.004

Prince, A.J., E. Apostolopoulou, and M. Simonova. 2009. Nitrogen fertiliser supply and demand: Balances, outlook and drivers of change. Proceeding no.: 666. The Int. Fertiliser Soc., York, UK.

Pritchard, D.L., N. Penney, M.J. McLaughlin, H. Rigby, and K. Schwarz. 2010. Land application of sewage sludge (biosolids) in Australia: Risks to the environment and food crops. Water Sci. Technol. 62(1):48-57. doi:10.2166/wst.2010.274

Ragg, J.M., G.R. Beard, H. George, F.W. Heaven, J.M. Hollis, R.J.A. Jones et al. 1984. Soils and their use in Midland and Western England. Bulletin No.: 12. The Soil Survey of England and Wales, Harpenden, UK.

Reijnders, L. 2014. Phosphorus resources, their depletion and conservation, a review. Resour. Conserv. Recycling 93:32-49. doi:10.1016/j.resconrec.2014.09.006

Rigby, H., B.O. Clarke, D.L. Pritchard, B. Meehan, F. Beshah, S.R. Smith, and N.A. Porter. 2016. A critical review of nitrogen mineralization in biosolids-amended soil, the associated fertilizer value for crop production and potential for emissions to the environment. Sci. Total Environ. 541:1310-1338. doi:10.1016/j. scitotenv.2015.08.089

Rigby, H., and S.R. Smith. 2014. The nitrogen fertiliser value and other agronomic benefits of industrial biowastes. Nutr. Cycl. Agroecosyst. 98(2):137-154. doi:10.1007/s10705-014-9602-4

Sadras, V.O., and D. Rodriguez. 2010. Modelling the nitrogen-driven trade-off between nitrogen utilisation efficiency and water use efficiency of wheat in eastern Australia. Field Crops Res. 118(3):297305. doi:10.1016/j.fcr.2010.06.010 
Schoeningh, E. 1994. Advantages of nutrient application with homogeneous NPK complex fertilizers as compared with different straight fertilizer systems. In: R.G. Lee, editor, Proceedings International Workshop Nitric Acid-based Fertilizers and the Environment. Special Publication International Fertilizer Development Center 21:83-94. IFDC, Muscle Shoals, AL.

Shaohua, Y., Q. Junyao, and Z. Zhenhua. 1999. Comparison of mathematical models for describing crop responses to $\mathrm{N}$ fertilizer. Pedosphere 9(4):351-356.

Shober, A.L., and J.T. Sims. 2003. Phosphorus restrictions for land application of biosolids: Current status and future trends. J. Environ. Qual. 32(6):1955-1964. doi:10.2134/jeq2003.1955

Sibbesen, E., and A.N. Sharpley. 1997. Chapter 7: Setting and justifying upper critical limits for phosphorus in soils, 151-176 pp. In: $\mathrm{H}$. Tunney, O.T. Carton, P.C. Brookes, A.E. Johnston, editors, Phosphorus loss from soil to water. CAB Int., Wallingford, Oxon, UK.

Sinclair, T.R. 1998. Historical changes in harvest index and crop nitrogen accumulation. Crop Sci. 38(3):638-643. doi:10.2135/cropsci 1998.0011183X003800030002x

Singh, B.R., and R.P. Narwal. 1984. Plant availability of heavy metals in a sludge-treated soil: II. Metal extractability compared with plant metal uptake. J. Environ. Qual. 13(3):344-349. doi:10.2134/jeq1984.00472425001300030004x

Skinner, R.J., and A.D. Todd. 1998. Twenty five years of monitoring $\mathrm{pH}$ and nutrient status of soils in England and Wales. Soil Use Manage. 14(3):162-169. doi:10.1111/j.1475-2743.1998.tb00144.x

Slafer, G.A. 2003. Genetic basis of yield as viewed from a crop physiologist's perspective. Ann. Appl. Biol. 142(2):117-128. doi:10.1111/j.1744-7348.2003.tb00237.x

Slafer, G.A. 2007. Physiology of determination of major wheat yield components. In: H.T. Buck, J.F. Nisi, and N. Salomon, editors, Wheat production in stressed environments, 795. Vol. 12 of the Series Developments in Plant Breeding. Springer, the Netherlands. doi:10.1007/1-4020-5497-1_68 p. 557-595.

Slafer, G.A., and F.H. Andrade. 1993. Physiological attributes related to the generation of grain yield in bread wheat cultivars released at different eras. Field Crops Res. 31(3-4):351-367. doi:10.1016/0378-4290(93)90073-V

Slafer, G.A., and H.M. Rawson. 1994. Sensitivity of wheat phasic development to major environmental factors: A re-examination of some assumptions made by physiologists and modellers. Funct. Plant Biol. 21(4):393-426. doi:10.1071/PP9940393

Smith, S.R. 2009. Organic contaminants in sewage sludge (biosolids) and their significance for agricultural recycling. Philos. Trans. R. Soc. London A: Mathematical, Physical. Eng. Sci. 367:40054041. doi:10.1098/rsta.2009.0154

Smith, M.T.E., B.J. Cade-Menun, and M. Tibbett. 2006. Soil phosphorus dynamics and phytoavailability from sewage sludge at different stages in a treatment stream. Biol. Fertil. Soils 42(3):186-197. doi:10.1007/s00374-005-0014-0

Smith, G.H., K. Chaney, C. Murray, and M.S. Le. 2015. The effect of organo-mineral fertilizer applications on the yield of winter wheat, spring barley, forage maize and grass cut for silage. J. Environ. Prot. (Irvine Calif.) 6(2):103-109. doi:10.4236/ jep.2015.62012
Smith, L.P., and B.D. Trafford. 1976. Climate and drainage. MAFF Technical Bull. 34. The Stationery Office, London.

Sommers, L.E., D.W. Nelson, and K.J. Yost. 1976. Variable nature of chemical composition of sewage sludge. J. Environ. Qual. 5(3):303-306. doi:10.2134/jeq1976.00472425000500030017x

Sparrow, P.E. 1979. The comparison of five response curves for representing the relationship between the annual dry-matter yield of grass herbage and fertilizer nitrogen. J. Agric. Sci. 93(3):513-520. doi:10.1017/S0021859600038910

Sylvester-Bradley, R., D.R. Kindred, S.C. Wynn, R.E. Thorman, and K.E. Smith. 2014. Efficiencies of nitrogen fertilizers for winter cereal production, with implications for greenhouse gas intensities of grain. J. Agric. Sci. 152(1):3-22. doi:10.1017/ S0021859612000810

Talibudeen, O., M.B. Page, and J.D.D. Mitchell. 1976. The interaction of nitrogen and potassium nutrition on dry matter and nitrogen yields of the graminae: Perennial ryegrass (Lolium perenne). J. Sci. Food Agric. 27(11):999-1004. doi:10.1002/jsfa.2740271104

Tejada, M., C. Benítez, and J.L. González. 2002. Nitrogen mineralization in soil with conventional and organomineral fertilization practices. Commun. Soil Sci. Plant Anal. 33(19-20):3679-3702. doi:10.1081/CSS-120015915

Tottman, D.R., R.J. Makepeace, and H. Broad. 1979. An explanation of the decimal code for the growth stages of cereals, with illustrations. Ann. Appl. Biol. 93(2):221-234. doi:10.1111/j.1744-7348.1979.tb06534.x

UKWIR. 2015. Biosolids: Good practice guidance. Water Industry Research Ltd., London. http://www.water.org.uk/publications/ reports/biosolids-good-practice-guidance (accessed 27 Jan. 2017).

Vaneeckhaute, C., J. Janda, P.A. Vanrolleghem, F.M.G. Tack, and E. Meers. 2016. Phosphorus use efficiency of bio-based fertilizers: Bioavailability and fractionation. Pedosphere 26(3):310-325. doi:10.1016/S1002-0160(15)60045-5

VSN International Ltd.. 2013. GenStat Release, 16th ed. Reference manual. VSN Int. Ltd., Hemel Hempstead, U.K.

Wang, Y.T., T.Q. Zhang, I.P. O’Halloran, C.S. Tan, and Q.C. Hu. 2016. Predicting environmental soil phosphorus limits for dissolved reactive phosphorus loss. Soil Use Manage. 32(1):60-68. doi:10.1111/sum.12238

Welsh, J.P., G.A. Wood, R.J. Godwin, J.C. Taylor, R. Earl, S. Blackmore, and S.M. Knight. 2003. Developing strategies for spatially variable nitrogen application in cereals, Part II: Wheat. Biosystems Eng. 84(4):495-511. doi:10.1016/S1537-5110(03)00003-5

White, E.M., and F.E.A. Wilson. 2006. Responses of grain yield, biomass and harvest index and their rates of genetic progress to nitrogen availability in ten winter wheat varieties. Ir. J. Agric. Food Res. 45(1):85-101.

Withers, P.J.A., N.J. Flynn, G.P. Warren, M. Taylor, and B.J. Chambers. 2016. Sustainable management of biosolid phosphorus: A field study. Soil Use Manage. 32(1):54-63. doi:10.1111/ sum. 12235

Withers, P.J.A., H. Hartikainen, E. Barberis, N.J. Flynn, and G.p. Warren. 2009. The effect of soil phosphorus on particulate phosphorus in land runoff. Eur. J. Soil Sci. 60(6):994-1004. doi:10.1111/j.1365-2389.2009.01161.x 